\title{
Organizational ambidexterity: using project portfolio management to support project-level ambidexterity
}

Yacoub Petro (email: Yacoub.Petro@stantec.com)

Stantec UK Limited, United Arab Emirates

Udechukwu Ojiako (email: udechukwu.ojiako@ outlook.com)

College of Engineering, University of Sharjah, United Arab Emirates

Hull University Business School, University of Hull, United Kingdom

UNIZIK Business School, Nnamdi Azikiwe University, Nigeria

Terry Williams (email: terry.williams@ hull.ac.uk)

Hull University Business School, University of Hull, United Kingdom

\author{
Alasdair Marshall (email: a.marshall@ soton.ac.uk) \\ Southampton Business School, University of Southampton, United Kingdom
}




\begin{abstract}
The aim of this study is to assess the ability of project portfolio management practices to support the pursuit of ambidexterity at the project level through engagement with specific dimensions and mechanisms. The focus is on examining the operating/business model and challenges that are imposed on the firms, but deemed resolvable through the simultaneous pursuit of multiple projects emphasising contradictory strategic goals. Data are obtained from multiple exploratory interviews of senior executives involved in project-level activities who were drawn from twelve case organisations in the Middle East. The study finds evidence of four forms of ambidexterity dimensions and mechanisms. Analysis undertaken against operating/business model and challenges of these dimensions and mechanisms of ambidexterity suggests that they are not only inter-related, but do so at various organisational levels.
\end{abstract}

Keywords: Organizational ambidexterity, Ambidexterity mechanisms; Projects, Portfolio management

\title{
1. Introduction
}

\subsection{Projects in operations}

The literature suggests that projects represents critical drivers for operationalizing the visions of organisations (Ojiako et al. 2015; Maylor et al. 2018). Due to their ephemeral nature (see Turner et al. 2015; Prado and Sapsed 2016), the mutuality of its interdependent processes (Turner and Lee-Kelley 2013) and temporal switching ability (Liu and Leitner 2012; Kortmann et al. 2014), projects serve as the ideal conduit for managing distinct routines that encompass operations (Hayes 2002).

Extensive research has been undertaken within the strategic management (Wassmer et al., 2017) and project management discipline (Kornfeld and Kara 2011; Martinsuo 2013) examining to what extent organisations may be better off pursuing single as against a multiple number of project initiatives and whether organisations have the competency simultaneously to pursue multiple projects that emphasise contradictory strategic goals (Wassmer et al. 2017). Studies appear to suggest that most organisations rarely undertake to deliver single projects (Eriksson 2013). In fact, there is acknowledgement in the literature that while there are considerable advantages for organisations to direct their resources delivering single project initiatives, doing so could lead at a certain tipping point to declining returns. To counter the potential for such an occurrence, most organisations introduce and manage simultaneously, a continuous range of multiple concurrent projects in the form of 'portfolios'. Managing a project portfolio requires a broad perspective of projects that departs from construing each project as an independent entity. In a portfolio, while each project is independent, collectively, they are interdependent 
(connected to other projects via resource sharing), thus makes a contribution (however discrete) to the viability of the entire portfolio (Verma et al. 2011).

\subsection{The project portfolio imperative}

Organisations conceive portfolios as “.... group of projects that are carried out under the sponsorship and/or management of a particular organization" (Archer and Ghasemzadeh 1999, p. 208). Herein, portfolios serve as a means of sharing resources among multiple concurrent projects which are perhaps smaller than would justify the dedication of specific ring-fenced resources (Verma and Sinha 2002; Kopmann et al. 2017). Portfolios provide organisations with the opportunity to enable different projects simultaneously access critical resources that reside within the boundaries of other projects. This allows for process efficiencies to be attained. By pursuing multiple projects at the same time, organisations can also ensure that risk are widely spread (Wassmer et al. 2017). Furthermore, project portfolios can provide learning benefits as organisations develop their experience base gleaned from the different projects.

Although project portfolios accord organisations a number of advantages, portfolios are associated with a number of unintentional negative consequences. One such consequence is the increase in the demands for information processing and greater costs of coordination due to stakeholder heterogeneity (Ojiako et al. 2015a). Key project stakeholders within organisations may express different preferences for individual projects within their portfolio given limited resources. Project stakeholders with a preference for predictability, high task certainty and who are risk averse may support projects which are designed within the realm of pre-existing organisational competencies (Chipulu et al. 2019). These projects are by implication more likely to involve standard practice (articulated in policy and other methodology-based documentation - see Verma et al. 2011). On the other hand, project stakeholders who are more inclined to opportunity seeking and who are neither risk averse nor concerned about high task uncertainty may seek to stretch or innovate on current competencies and by implication explore new ideas.

In order to reduce information processing and coordination costs associated with project portfolio management (henceforth 'PPM'), organisations can among various approaches seeks to seamlessly balance or re-negotiate the various tensions experienced within these portfolios. When an organisation over-invests in exploitative as against explorative projects, they are likely to enjoy success from exploiting existing competencies, but in the face of major changes in technology, such success is unlikely

to sustain strategic competitiveness as those competencies become outdated and begin to represent the core rigidities of tomorrow (see Leonard-Barton 1992). At the same, when an organisation over-invests 
in exploitative projects, it will begin to encounter significant costs due to its engagement with constant search activities (Cao et al. 2009). According to Piao and Zajac (2016), being engaged in repetitive exploitative initiatives by an organisation is only likely to degrade its ability to develop explorative capabilities and in the process proactively engage with dynamic changes to their business environment. Such organisations will also likely experience "success trap" if emphasis is predominantly on for example projects (portfolios) that emphasise the exploitation of existing initiatives (Levinthal and March 1993, p.106). On the other hand, where there is predominant emphasis on exploring new (strategic) initiatives, "failure traps" becomes more of a reality (Levinthal and March 1993, p.105). Herein, an organizations ability to simultaneously manage different projects (with different objectives and a host of other imperatives such as stakeholder interests) within a portfolio will be driven by a number of core capabilities - one being ambidexterity (Fernhaber and Patel 2012).

\subsection{Ambidexterity}

As a maturing research concept and theoretical prism, ambidexterity, which involves "....the ability to

simultaneously pursue both incremental and discontinuous innovation and change..." (Tushman and O'Reilly 1996, p. 24). Ambidexterity is increasingly attracting the attention of scholars in the field of project management (Aubry and Lièvre 2010; Leybourne and Sainter 2012; Eriksson 2013; Turner and Lee-Kelley 2013; Turner et al. 2013a, 2013b, 2014, 2015, 2016a,b; 2018) and the wider operations management discipline (Kortmann et al. 2014; Sohani and Singh 2017). As a theoretical prism, ambidexterity is not only one of the theories that is currently being extended into project management from operations management (Maylor et al. 2018), but it has also been utilised as a prism to explore a number of project management concepts including for example complexity. For example, Turner et al. (2018) claims that instead of a traditional view of complexity as a construct to be either reduced or resolved, an ambidextrous perspective will imply the concurrent "accommodation" and "minimisation" of complexity. Ambidexterity is a lens that recently has increasingly begun to be used within Production Planning \& Control (see for example, Esposito de Falco et al 2017; Love et al 2018). The interest among scholars on ambidexterity appears driven by its versatile and pervasive nature and application to various disciplines (Birkinshaw and Gupta 2013; Turner et al. 2013a).

\subsection{Ambidexterity and PPM}

From our understanding of the literature, PPM is critical to successfully achieving ambidexterity. In fact, as both Eriksson (2013) and Sinha (2016) has emphasised, the conflict and/or tensions associated with 
ambidexterity can be addressed by adopting PPM. Here, PPM can help manage not only the interfaces and interdependencies that arise between projects pooled within the same portfolio, but the contradictions associated in managing projects with different and contradictory expectations. Since the argument goes that organisations that are able to simultaneously pursue multiplicity are more likely to exhibit superior performance (Fernhaber and Patel, 2012), it is reasonable to posit that PPM is able through its role in simultaneousity to enhance organisational ambidexterity and by implication, organisational performance. We argue therefore that PPM complements a number of benefits of ambidexterity. Thus, an organisation with a substantially level of PPM competency will be able to not only effectively manage concurrent projects, but also be able to manage existing projects while developing newer ones, even ones with conflicting project goals and strategic objectives.

It then follows that project portfolios may be a crucial means of achieving firm ambidexterity (Bresciani et al. 2017; Wassmer et al. 2017). This occurs because through alliances, organisations gain access to networks outside their firm boundaries and are able to draw upon through their external alliance partners, new resources that are able to complement resources which already exist internally (Bresciani et al. 2017; Wassmer et al. 2017). In addition, through alliance partners, organisations are able to for example choose to focus their efforts on exploration and value creation while delegating/shifting less value creating activities (exploitation) to their alliance partners. Thus, Bresciani et al. (2017) claims that alliances are an important means by which organisations release internal resources from the dual challenge of simultaneous exploration and exploitation - in effect, contradictory expectations. The point which must however be noted from alliance literature (for example, Tiwana 2008), is that while PPM may create an opportunity for managing ambidexterity, optimised PPM cannot discount the need for effective management of individual projects (Gerwin and Ferris 2004). In fact, Tiwana (2008) opines, "...the successful accomplishment of novel projects requires the heterogeneity of capabilities and expertise provided by bridging ties among alliance partners" (p. 251). Not only are projects utilised to drive value in most businesses, but also it is at the project level (due to its transient, ephemeral and atypical nature) as against the portfolio level that the visions of organisations are operationalized and ambidexterity is likely to be best actualised (Turner and Lee-Kelley 2013; Petro et al. 2018).

\subsection{The research question}

Mindful of scholarship calling for increased empirical studies in operations (Choi et al. 2016) and project management (Geraldi and Söderlund 2018), project management is a discipline which is oriented towards practical application (Cicmil et al. 2006; Blomquist et al. 2010). Cicmil et al. (2006) for example 
emphasises the need for research that "takes seriously practitioner's lived experience of projects" (p. 675). Blomquist et al. (2010) espouses the need for project management research that is relevant - in the form of "project-as-practice" (p. 5). However, as relates to ambidexterity at the project level, Turner and Lee-Kelley (2013) has pointed out that "there is limited theorisation and empirical evidence within the literature on how exploitation and exploration are achieved in practical, team-based operations" (p.180). This point is reiterated in his later works (see Turner et al. 2013a; Turner et al. 2016a) and the works of Liu et al. (2012) and Sohani and Singh (2017) who assert that while there is substantial research is available on organisation-level ambidexterity, insight on project-level ambidexterity is largely meagre. To reinforce this claim, Petro et al. (2018) opined in their recent taxonomical analysis of the elements and components of project-level ambidexterity that as a term, 'ambidexterity' does not appear in a number of project practitioner management practice manuals.

While available research broadly provides us with a wide range of ideas on how to manage project portfolios, it will appear that there are still areas of the operations and project management literature that remains unsettled as relates to firstly the specific dimensions and mechanisms required to achieve projectlevel ambidexterity (Turner and Lee-Kelley 2013; Turner et al. 2013a; Turner et al. 2016b; Petro et al. 2018) and how secondly, how these dimensions and mechanism are best operationalized at the project level for relevance to project management practice. Taking all this into consideration, our research question is presented as:

RQ: How can project portfolio management (PPM) facilitate ambidexterity in project-based organisations?

\section{Overview of prior literature}

\subsection{Types, levels, dimensions and mechanisms of ambidexterity}

A review of the academic literature suggests that ambidexterity is actualised in the form of multiple types, across different organisational levels (see Birkinshaw and Gupta 2013; Kassotaki et al. 2018), is of different dimensions (Sohani and Singh 2017; Petro et al. 2018) and actualised via a number of different mechanisms (O'Reilly and Tushman 2011; Turner et al. 2013a). Understanding of these constructs (types, levels, dimensions and mechanisms) is in line with assertions made earlier by He and Wong (2004) on the need to understand the "...different structures, processes, strategies, capabilities, and cultures to pursue and may have different impacts on firm adaptation and performance [of ambidexterity]" (p. 481). 
Recent studies by Petro et al. (2018) asserts the existence of different levels, dimensions and mechanisms of a project-focused typology of organisational ambidexterity.

2.1.1 Types of ambidexterity: Extant ambidexterity research has construed ambidexterity from three different but complementary perspectives which includes firstly 'structural ambidexterity' - which emphasised the creation of different autonomous organisational subunits deemed separated structurally, each operating with different resources and utilising different processes (Jansen et al. 2009; Mom et al. 2009; O'Reilly and Tushman 2011). Structural ambidexterity can be actualised in a number of ways. One way is through 'temporal switching' (O'Reilly and Tushman 2011) which allows for the oscillation (swinging) between for example formal and informal project structures, processes and different or alternate strategic focus. Not exhibiting the flexibility required to undertake 'temporal switching' means that it is possible that the organisation ends up over-investing or emphasising projects which are focused on exploitation as against exploration (or vice-versa). Liu et al. (2012) suggests that 'structural ambidexterity' is not appropriate for project-related work because of the need for project teams to be integrated and as far as possible, co-located. Another type of ambidexterity is 'sequential ambidexterity' where the differentiation emphasised organisations emphasising focusing first on one initiative, and then on its completion on another (Eriksson 2013). The third and final type of ambidexterity is 'contextual ambidexterity' which involves the simultaneous pursuit of exploration and exploitation within a specific entity (Gibson and Birkinshaw 2004; Zimmermann et al. 2015). The emphasis is on the use of behavioural and social interactions to facilitate employee empowerment that enables ambidexterity. While recent studies suggest that a combination of these different forms of ambidexterity may be more beneficial to organisations (see Zimmermann et al. 2015, 2018; Wassmer et al. 2017), contextual ambidexterity is deemed to be the most effective means of actualising ambidexterity at the project level (Liu et al. 2012).

2.1.2 Levels of ambidexterity: From Sohani and Singh (2017) and Petro et al. (2018), we have come to understand levels as decision points that reside at the point of the individual project manager. Defined by Rousseau (1985, p. 3/4) as "the hierarchical relationship and attributes of the constituent elements of an organisation", levels of ambidexterity can refer to the level of the individual (in this case project manager), the organisational or the social level (Turner et al. 2013). It can also refer according to Petro et al. (2018) to the individual, project, operations and strategic perspective of ambidexterity. Li et al. (2008) undertook quite substantial work examining the operationalization at different levels finding for 
example that at the individual level, exploitation and exploration were deemed as distinct. They also found that at the project level, exploration was construed by the level of focus of the project on new developments. At the individual project manager level, the authority to make decisions has a positive impact on competency for ambidexterity competency, however formalizing project tasks allocation will not appear to have any major impact on their ambidexterity competency (Mom et el. 2009). A natural extension of the study by Mom et al. (2009) is Aubry and Lièvre (2010) and Lin and McDonough (2011), both which explored how project leadership impacted upon ambidexterity.

The organisational level appears to be an area of considerable interest among scholars, attracting arguably the highest amount of empirical research (Turner et al. 2013b). Similar to the individual level, exploitation and exploration were deemed as distinct at the firm level, however at firm level, this distinction appeared focused on exploitation as the search for 'near' knowledge search and exploration as the search for 'distant' knowledge. Levels can also encompass sub-elements for example, within the organisation. This may include for example the level of the firm and the employee (Kassotaki et al. 2018) and also functional units and/or the project (Turner et al. 2013; Kassotaki et al. 2018).

Across the employee level, scholars have for example been interested in understanding the role of top-managers/executives in actualising ambidexterity (García-Granero et al. 2017). More recent studies by Zimmermann et al. (2018) provides very intriguing insights into on top-managers/executives in actualising ambidexterity by suggesting that as against general conventional understanding on the role of top-managers/executives in actualising ambidexterity, it is in fact frontline managers (such as project managers) that perhaps the more proactive and central role in enacting ambidexterity. Benner and Tushman (2003) generally, conceptualise the project level as representative of the "...multiple tightly coupled subunits that are themselves loosely coupled with each other" (p. 242). Generally, the studies by Turner et al. (2013b) suggests that at the functional level of the organisation, due to extreme complexity, there is a need for intense resourcing and processes (mechanisms)to support project-level ambidexterity.

2.1.3 Dimensions of ambidexterity: When we consider dimensions, we refer to specific project-based attributes that are capable of creating paradoxes which will make a demand for resolution in before the performance of projects could be enhanced (Petro et al. 2018). More specific to projects, Petro et al. (2018), identified four dimensions of ambidexterity which included knowledge (an organised form of ideas), technology (seen to imply a practice-focused application of science), process (which referred to multi-level routines - although one concern from a project management perspective related to the 
perceived constraining role of project management bodies of knowledge) and behaviour (where the focus had been a need to resolve behavioural tension).

Cao et al. (2009) does not conceptualise dimensions as relating to paradox-creating organisational features. Instead they conceptualise dimensions as operationalizing constructs. To cater for ambidexterity, two such dimensions are identified. First, the "balanced dimension" which appeared to conceptualise ambidexterity as comprising of two purely distinct and independent constructs (exploitation and exploration) on which organisations have to oscillate in between. This dimension appears more suitable to firms facing resource constraints. Second is the "combined dimension" which construes these two constructs as corresponding to the combined form of the "balanced dimension". Organisations that are more suitable to this dimension are those that have more access to various resources. According to Cao et al. (2009), the distinction between the two dimensions relate mainly to their operationalisation requiring different mechanisms. Herein, organisations that have readily available resources are more likely to be able to pursue at the same time exploitation and exploration.

2.1.4 Mechanisms of ambidexterity: Mechanisms on the other hand are seen to represent those “...processes, systems and structures” (Turner et al. 2013a; p. 318) and “...specific managerial actions” (O'Reilly and Tushman 2011, p. 8) that facilitate the simultaneous pursuit of exploitation and exploration. Through these mechanisms, organisations are able to exploit and leverage resources for their simultaneity across multiple projects (portfolios) with inconsistent and conflicting objectives (Turner et al. 2013a).

Thus, mechanisms serve as enablers of ambidexterity (Turner and Lee-Kelley 2013). These mechanisms may be formal or informal although according to Jansen et al. (2009) ambidexterity is more likely to be enacted through formalized mechanisms.

In Jansen et al. (2005) three coordinating mechanisms for ambidexterity were identified as (i) decentralization which focused on delegated authority within the hierarchy of organisations (ii) formalization which addressed the extent to which organisational routines (in the form of rules and procedures) were captured in formal forms and (iii) connectedness, in order words, the nature of the governance arrangements within an organisation (for example, in the case of projects - what role the project management office may perform to enable ambidexterity - see Turner and Lee-Kelley 2013). Their work was extended in Jansen et al. (2009) where four mechanisms of ambidexterity integration were identified as (i) senior team (ii) organizational (iii) formal and (iv) informal integration. Turner et al. (2013a) focusing on sub-organisational units (such as projects) identified three intellectual capital resources (organizational, social and human capital) as complementary to the generic mechanisms of 
ambidexterity. Turner et al. (2013a) were influenced to explore these mechanisms or specific managerial actions because a lack of practical understanding of the realities of such managerial action was likely to limit the effectiveness of project-portfolio management (PPM) practices. This position was largely driven by a recognition that the core ambidexterity resources (intellectual capital in the form of human, social and organisational capital) that support those mechanisms coexist in the form of the two constructs of ambidexterity (exploitation and exploration). Lin and McDonough's (2014) exploration of mechanisms of ambidexterity represented a slight departure from the direction that Turner (... and Lee-Kelley 2013; et al. 2013a, et al. 2016a) and later on Petro et al. (2018) had taken which had focused on mechanisms from a processes, systems and structural perspective. Instead, emphasising specific managerial actions, they had emphasised mechanisms as cognitive framing related to individual manager knowledge acquisition, learning and idea exchange.

Reverting to the process, systems and structural perspective of mechanisms, Beverland et al. (2015) focus was on process design. Petro et al. (2018) identified four mechanisms - (i) structural, (ii) learning, (iii) selection/allocation and (iv) communication. Among the main contributions of the study by Turner (...and Lee-Kelley 2013; et al. 2013a, et al. 2016a) and that of Petro et al. (2018) is that in taking into consideration how the project-contextualised ambidexterity literature has evolved over the years, both sets of studies (that is Turner et al. 2013a; Petro et al. 2018) have been able not only to facilitate more detailed understanding in terms of how ambidexterity may be achieved as in the case of Turner et al. (2013a) and Petro et al. (2018), but also provided opportunities for exploring a possible expanded definition of ambidexterity that is project focused as in the case of Petro et al. (2018). However, both sets of studies are limited in that being primarily literature driven, they do not provide any knowledge that is derived from any observed or measureable phenomena of actual experience.

To summarise, what appears to be the case is that through a combination of these different mechanisms, organizations gain the ability to adjust and synchronize the relationships between its various units, systems and processes hereby becoming ambidextrous. Geerts et al. (2018) refers to spatial ambidexterity as an ambidexterity mechanism that focuses on driving ambidexterity based on geographical proximate locations.

\subsection{Beyond types, levels, dimensions and mechanisms}

It is important to acknowledge that project-focused ambidexterity has covered a much wider breath than ambidexterity's four constructs (types, levels, dimensions and mechanisms). For example, projectfocused ambidexterity literature has ranged from Lee et al. (2006) which focused on coping strategies in 
ambidextrous project environments to studies by Liu and Leitner (2012) focused on understanding how ambidexterity impacts upon the performance of projects. Lee et al. (2006) found that strategies to cope with ambidexterity in projects were more pronounced in larger globally-focused projects than projects of smaller sizes. Both Hoang and Rothaermel (2010) and Liu and Leitner (2012) sought to understand project performance from an ambidexterity perspective. Hoang and Rothaermel (2010) focused on the nature of the impact of an organisation's alliance activities and project performance. Drawing on ambidexterity literature, they suggested that exploiting alliances were more likely to enhance project performance. On the other hand, exploration primarily due to the efforts likely to be expended on search, was more likely to have a negative effect on project performance. Their study supports assertions made later by Eriksson (2013) who found that due to their ephemeral nature (see also Turner et al. 2015), project performance was more likely to derive from a focus on exploitation as against exploration. This position appears also to have been shared by Leybourne and Sainter (2012). Liu and Leitner (2012) on the other hand focused their study on how that structural separation as a mechanism of ambidexterity may impact upon the performance of projects. Their findings suggests that structural separation was largely not an effective mechanism in enhancing project performance. In Turner and Lee-Kelley (2013) particular attention was paid to the role of project management offices (PMOs) in the achievement of ambidexterity. Here it was observed that PMOs allowed for the concurrent and simultaneous boundary spanning examination of multiple levels of ambidexterity (see also Julian, 2008). The use of PMOs allowed for concurrent focus on the individual project at the same time as a focus of the strategic interest of portfolios. Sohani and Singh (2017) examined the processes and routines utilised to operationalise ambidexterity finding amongst others that the nature of the interaction among various individual actors across different functional units (including at the level of the portfolio) of the organisation played a major role in the success of any operationalisation of ambidexterity. In Turner et al. (2018), drawing from project management literature, ambidexterity was utilised as a theoretical prism to explore responsiveness to complexity.

The alluded versatility and pervasiveness of ambidexterity has also become an occasional conversation within the wider operations management (Gaiardelli et al. 2015; Maylor et al. 2018). Indeed from an operations management perspective, ambidexterity was a key theme in the 2015 special Issue of Production Planning and Control "The strategic transition to services" (see Gaiardelli et al. 2015), the emphasis, perhaps not surprising, being on innovation. For example, Esposito de Falco et al (2017) discuss the effect of impact of collaborative innovation on firm ambidexterity; Roldán Bravo et al (2017) 
also on the theme of innovation tie ambidexterity to the different learning styles within the organisation, a theme we shall return to in this paper.

\section{The study}

\subsection{Overview}

Our study was undertaken in a form consistent with a fine-grained comparative case study. The earlier literature reviewed served two purposes. Firstly, it influenced the design of the field investigation questionnaire employed in the study. Secondly, we drew on this literature to determine the initial categories or codes to be utilised during data analysis. Our contention is that utilising comparative case study analysis of multiple cases is more advantageous than the use of a single-case study, as findings are more likely to be deeply grounded in empirical evidence drawn from multiple perspectives (Eisenhardt and Graebner 2007). The research endeavoured to target operationally relevant case organisations, in particular organisations which had demonstrated some form of ambidextrous capabilities.

\subsection{Unit of analysis}

Reference to unit of analysis implies according to Mead (1938), an interest in understanding behaviour. This position is in line with the sociological traditions of verstehende (Weber 1949) which reiterates the need to focus more on actions as against according importance to individual actors. The unit of analysis in this study therefore focuses on the actions taken by the individual managers (as interviewees), herein the meaning of such behaviour being an objective of our reflection. It is expected that this focus will enhance the practical relevance of the information to be gleaned during the interviews (Kozinets 2002).

\subsection{Data collection}

Data are obtained from multiple exploratory interviews of senior executives drawn from twelve case organisations, all with considerable business operations in the Middle East. One manager from each firm was interviewed (twelve in total) (Table 1), representing the minimum indicative number in Sandberg (2000) required to achieve saturation. The interviews were conducted over a three month period between November 2016 and January 2017. Each of those interviews lasted approximately between 75 and 120 minutes. The selected respondents were identified professional networks (primarily the Project Management Institute). Initial contact with the interviewees was through LinkedIn or directly via email. 
Table 1: Overview of interviewees

\begin{tabular}{|c|c|c|c|c|c|c|}
\hline$\underset{\Xi}{\Xi}$ & $\begin{array}{l}\text { Type of } \\
\text { services }\end{array}$ & Country of operation & $\begin{array}{c}\text { Year } \\
\text { founded }\end{array}$ & $\begin{array}{c}\text { Number of } \\
\text { employees } \\
\text { (approximate) }\end{array}$ & $\begin{array}{c}\text { Annual } \\
\text { revenue } \\
\text { (millions) }\end{array}$ & Interviewees \\
\hline 1 & $\begin{array}{l}\text { Engineering } \\
\text { consultant }\end{array}$ & $\begin{array}{l}\text { UAE, Qatar, Bahrain, } \\
\text { Kuwait }\end{array}$ & $\sim 1960$ & 200 & $\$ 25.00$ & $\begin{array}{l}\text { Director of } \\
\text { Operations }\end{array}$ \\
\hline 2 & $\begin{array}{l}\text { Engineering } \\
\text { consultant }\end{array}$ & $\begin{array}{l}\text { Egypt, UAE, Qatar, } \\
\text { KSA }\end{array}$ & $\sim 1960$ & 1,000 & $\sim \$ 50.0$ & $\begin{array}{l}\text { General } \\
\text { Manager }\end{array}$ \\
\hline 3 & $\begin{array}{l}\text { Logistics- } \\
\text { large-scale } \\
\text { projects }\end{array}$ & Jordan & 2003 & UI and Subs & UI & $\begin{array}{l}\text { Treasury } \\
\text { Manager }\end{array}$ \\
\hline 4 & $\begin{array}{l}\text { Management } \\
\text { consultant }\end{array}$ & UAE & 2005 & Between 15 and $40^{*}$ & $\$ 9.00$ & $\begin{array}{l}\text { Business } \\
\text { Development } \\
\text { Manager }\end{array}$ \\
\hline 5 & Manufacturer & UAE, Qatar, KSA & 2000 & UI & UI & $\begin{array}{l}\text { Managing } \\
\text { Director }\end{array}$ \\
\hline 6 & $\begin{array}{l}\text { Humanitarian } \\
\text { projects }\end{array}$ & Egypt, UAE, KSA & 2006 & 300 & $\$ 600.00$ & $\begin{array}{l}\text { Local } \\
\text { Manager UAE }\end{array}$ \\
\hline 7 & $\begin{array}{l}\text { Recycling and } \\
\text { manufacturing }\end{array}$ & KSA & 1988 & 1,500 & $\$ 650.00$ & $\begin{array}{l}\text { Operations } \\
\text { Manager }\end{array}$ \\
\hline 8 & $\begin{array}{l}\text { Specialized } \\
\text { DBO } \\
\text { contractor }\end{array}$ & UAE, Libya & 2000 & $56^{*}$ & $\sim \$ 100.0$ & $\begin{array}{l}\text { Project } \\
\text { Director }\end{array}$ \\
\hline 9 & Contractor & Jordan & 1981 & 200 & $\$ 150.00$ & $\begin{array}{l}\text { Head of } \\
\text { Projects } \\
\text { Control }\end{array}$ \\
\hline 10 & $\begin{array}{l}\text { Web } \\
\text { developers }\end{array}$ & $\begin{array}{l}\text { Jordan, KSA, Qatar \& } \\
\text { UAE }\end{array}$ & 2007 & 70 & $\$ 0.5-\$ 1.0$ & $\begin{array}{l}\text { Business } \\
\text { Development } \\
\text { Manager }\end{array}$ \\
\hline 11 & $\begin{array}{l}\text { Project } \\
\text { management } \\
\text { consultant }\end{array}$ & Qatar & 2014 & 600 & UI & $\begin{array}{l}\text { Technical } \\
\text { Manager }\end{array}$ \\
\hline 12 & $\begin{array}{l}\text { Energy } \\
\text { consultant }\end{array}$ & UAE, Jordan, KSA & 1991 & 35 & $\sim \$ 12.0$ & $\begin{array}{l}\text { Chief } \\
\text { Executive } \\
\text { Officer }\end{array}$ \\
\hline
\end{tabular}


UI: Unidentified/confidential | Subs: Heavily dependent on subcontractors and outsourcing | Revenue in US\$ million /year | Bold font: Regional headquarters

*Firm employed a large number of independent contractors

Our reference to 'senior executives' did not encompass 'board level' managers as contemplated by Oehmichen et al. (2017). Our focus was on managers who occupied positions that served as a link between the organisational and project-level (Taylor and Helfat 2009). The interviewees all carried enough influence and knowledge of the organization while also at the same time retaining daily operational control of project portfolios being implemented by the organisation.

All the interviewees came from project-based organisations. Two of the organisations were drawn from manufacturing, however as Grant and Pennypacker (2006) does point out, project management capabilities within the manufacturing industry is relatively high. While the firms arguably exhibited few similarities in their operation, their final outputs and outcomes were not necessarily different in that all sought to deliver products or/or services that were innovative and likely to enhance their competitiveness. Arguably, such similarities provides us with substantial opportunity for cross-case comparison and idea generation, thus facilitating meaningful insight into project-level ambidexterity.

Noting the growing use and noted advantages of telephone interviews over face-to-face interviewing (see Rogers 1976; Stephens 2007; Novick 2008), the interviews were conducted via telephone. The viability of telephone interviews was particularly drawn from Rogers (1976) who found that data quality from telephone interviews were comparable to that of face-to-face interviews. During the interviews, we were particularly mindful of the experiences reported by Stephens (2007) on his experiences conducting telephone interviews with elites (as arguably these group of interviewees were).

All interviews were conducted in English, although in all cases both interviewee and the interviewer were fluent Arabic speakers. The decision to conduct the interviews in English rather than Arabic was driven by a need to avoid any possible misrepresentation during interview transcription and the need for content ratification (Mero-Jaffe 2011). To further ensure that the informants were involved with organisational level decision-making, as suggested by Currall et al. (2015), an initial discussion took place with each of the interviewees, their superiors (where such existed) or their direct reportee; where non such reportees were identified, other employees within their organisations. This initial discussion served as a filtration process, especially since job titles are not really indicative of lines and levels of managerial responsibility in organisation (Baron and Bielby 1986).

\subsection{The interview protocols}


The questionnaire consists of ten core questions as shown in Table 2. The questions were devised to support the earlier identified research question (RQ). The questions were inspired by several similar studies that covered areas on portfolio management and/or ambidexterity. Table 2 takes the reader in tabular form through each question, the logic behind each questions being asked, and the literature or research from which those questions were either taken or inspired.

\section{Table 2: The interview questions}

\begin{tabular}{|c|c|c|c|}
\hline Question & The Question & Question description & $\begin{array}{l}\text { Source of } \\
\text { questions }\end{array}$ \\
\hline Q1 & $\begin{array}{l}\text { How many years has your } \\
\text { company been in operation? } \\
\text { Growing? Shrinking or } \\
\text { sustaining? }\end{array}$ & $\begin{array}{l}\text { Size of the organisation and whether the } \\
\text { organisation is in a growing or a shrinking mode- } \\
\text { this question tries to understand the extent of } \\
\text { ambidexterity for each case study organisation. }\end{array}$ & $\begin{array}{l}\text { O’Reilly and } \\
\text { Tushman (2011) } \\
\text { and Birkinshaw et } \\
\text { al. (2016). }\end{array}$ \\
\hline Q2 & $\begin{array}{l}\text { What do you do in the } \\
\text { business and what is your role } \\
\text { in doing that? }\end{array}$ & $\begin{array}{l}\text { The operation type of the organisation-this } \\
\text { question looks at the complexity of the organisation } \\
\text { and sees whether this has an effect on its } \\
\text { ambidexterity. }\end{array}$ & $\begin{array}{l}\text { Andriopoulos and } \\
\text { Lewis (2009) }\end{array}$ \\
\hline Q3 & $\begin{array}{l}\text { How do you describe the } \\
\text { market or the environment in } \\
\text { which you are operating? }\end{array}$ & $\begin{array}{l}\text { A description of how respondents perceive the } \\
\text { market - this question measures the relevance } \\
\text { between the organisation's own ambidexterity and } \\
\text { compares it with the dynamicity of the market and } \\
\text { environment. }\end{array}$ & Teece et al. (2016) \\
\hline Q4 & $\begin{array}{l}\text { How do you deal with the } \\
\text { challenges coming from this } \\
\text { external environment? }\end{array}$ & $\begin{array}{l}\text { This core question extracts and understands the } \\
\text { means and mechanisms each organisation addresses } \\
\text { its challenges with. }\end{array}$ & $\begin{array}{l}\text { O’Reilly and } \\
\text { Tushman (2011) }\end{array}$ \\
\hline Q5 & $\begin{array}{l}\text { What do you think you do } \\
\text { differently as an organisation } \\
\text { to sustain yourself or grow? }\end{array}$ & $\begin{array}{l}\text { This question measures the differentiating elements } \\
\text { organisations apply to fine tune their means and } \\
\text { mechanisms to overcome challenges. }\end{array}$ & $\begin{array}{l}\text { O’Reilly and } \\
\text { Tushman (2011); } \\
\text { Birkinshaw et al. } \\
2016\end{array}$ \\
\hline Q6 & $\begin{array}{l}\text { How do you define/select the } \\
\text { types of projects (or work) that } \\
\text { you deliver in your } \\
\text { organisation (whether this was } \\
\text { for internal or for external } \\
\text { purposes)? }\end{array}$ & $\begin{array}{l}\text { This question addresses PPM practices in } \\
\text { organisations - the question aims to see the } \\
\text { relevance between organisational ambidexterity and } \\
\text { its applied practices. }\end{array}$ & $\begin{array}{l}\text { PMI (2013); APM } \\
(2012)\end{array}$ \\
\hline
\end{tabular}




\begin{tabular}{|l|l|l|l|}
\hline Q7 & $\begin{array}{l}\text { To what extent (and how) } \\
\text { might project types be affected } \\
\text { by the external environment or } \\
\text { the market? }\end{array}$ & $\begin{array}{l}\text { This question looks at the types of the projects in } \\
\text { the organisation, whether those are of the } \\
\text { exploratory or the exploitative types, and then tries } \\
\text { to understand the relevance of the type with the } \\
\text { environment. }\end{array}$ & $\begin{array}{l}\text { Davies and Brady } \\
\text { (2016) }\end{array}$ \\
\hline Q8 & $\begin{array}{l}\text { Is there a certain procedure by } \\
\text { which your organisation } \\
\text { selects project or clients? Is } \\
\text { there a certain strategy that } \\
\text { they follow? }\end{array}$ & $\begin{array}{l}\text { This question also tackles PPM practices with more } \\
\text { emphasis on the outcomes of Question 7. }\end{array}$ & $\begin{array}{l}\text { PMI (2013); APM } \\
\text { Q2012) }\end{array}$ \\
\hline Q9 & $\begin{array}{l}\text { What sort of challenges, if } \\
\text { any, do you face in delivering } \\
\text { those projects? How do you } \\
\text { overcome these challenges? }\end{array}$ & $\begin{array}{l}\text { This is an exploitative type of a question, since it } \\
\text { asks about the specific challenges faced in the } \\
\text { this question tries to extract the different types of } \\
\text { challenges combined with probable means or } \\
\text { mechanisms for their resolution. }\end{array}$ & $\begin{array}{l}\text { Lewis (2009); } \\
\text { Eriksson (2013) }\end{array}$ \\
\hline $\begin{array}{l}\text { What sort of challenges, if } \\
\text { any, do you face with team } \\
\text { members? What do you do to } \\
\text { satisfy these challenges? }\end{array}$ & $\begin{array}{l}\text { Similar to Questions 4, 5, and 9, this question digs } \\
\text { into more challenges and tries to find the means of } \\
\text { resolving those challenges, but this time on the } \\
\text { individual level. }\end{array}$ & $\begin{array}{l}\text { Gibson and } \\
\text { Birkinshaw (2004) }\end{array}$ \\
\hline
\end{tabular}

A point of observation is that the interview protocol did not contain the word "ambidexterity". This was consciously done in order to ensure that any probable or obvious guidance to anticipated outcomes was avoided. In addition, of particular importance to the authors was the need to glean from the daily actions and routines of the interviews evidence of specific operationalizing constructs (which we referred to as dimensions) and managerial actions (which we referred to as mechanisms) of project-level ambidexterity. Furthermore, the authors were also cognizant of the reality that 'ambidexterity' was neither a term familiar to practicing managers (Birkinshaw and Gupta 2013) nor a term that appears in project practitioner management practice manuals (Petro et al. 2018).

\subsection{Data analysis}

Raw data was collected and then transcribed into useable information. To start with, the semi-structured questionnaire tested the ambidexterity of the case-study organizations before adding it to the list shown in Table 1. The semi structured questionnaire then investigated the challenges each of those case-study organizations faced during their day-to-day operation in order to identify and introduce dimensions and then mechanisms into the mix. A five-stage analytical process was adopted from Andriopoulos and Lewis 
(2009) and used to analyse the transcribed data. This process calls for a systematic analysis for the raw data as shown in the following detailed stage description.

\section{Stage 1. Identify patterns and broad categories in each of the case studies}

To start with, the collected data was investigated thoroughly to see if we could identify patterns or emerging structural designs of an organization or a case. In those patterns which we were able to identify, we recognised high-level resolutions for problems or challenges; those were categorized for later use. As a result of patterns' identification, we categorized challenges and resolutions for each of the case studies (i.e. a resolution indicates any such method or mechanism by which the challenge was resolved by). We also identified an operating or a business model attached to each of the cases or organizations. Each organisation's challenges, along with its business and/or operating model were examined separately in order to establish whether their analysis could lead to any such paradoxical situations that can pass for an ambidexterity challenge. It is worth noting here that it was not the intention of the field survey to explore paradoxical situations through which this study has identified as dimensions of ambidexterity, rather the intention was to address the research question in which a relation between ambidexterity and PPM was sought - i.e. the research question asked for a method which PPM can be used to "facilitate ambidexterity in project-based organisations", we therefore sensed that any such method shall be linked to a mechanism by which ambidexterity can be sought through and PPM can be operationalized with. In light of this, it was important to ascertain that those challenges, along with the business and operating models, were a product of a paradox for if they were not, the mechanisms generated by this field survey and analysis could be argued not belong to the theory under study.

Considering the above, and in order to achieve a good and a reliable analysis for such lengthy interviews, the relevant scripts were put into a standard format devised by the authors with the aim to facilitate information gleaning and further analyses, then, they were all transported into NVivo software. NVivo uses nodes as means to facilitate the required analysis; each node represents a category, or a sub category. The nodes can then be used in various ways to work through the analysis. The researcher can create as many nodes as they want using NVivio, and they can link all such nodes, and use them in various ways to achieve the results they aspire. With this in mind, we created parent nodes and identified one as the business/operating model and another one we called challenges. All such nodes were then subcategorized into 24 sub-codes. Parts of the script were then taken (copied) and saved under any such node whether a parent or a sub node - those part scripts can be referred to as references. The parent nodes (i.e. the high-level ones: business/operating model and challenges) received no fewer than 50 
references combined. Another parent node was created and called challenges with the aim to identify resolutions which will be used later to extract the required mechanisms from them (needed to answer the research question). The challenges node received no less than 53 references. During the analysis of the challenges and business/operating model references contradictory situations and/or statements were looked for to identify paradoxes.

\section{Stage 2. Link relevant concepts within each case}

Prior to discussing what concepts mean in this context, it is important to understand their relationship to the abovementioned nodes and how these nodes generated the referred-to concepts or vice versa. To facilitate this, please refer to Figures 1 and 2 and in particular to the first column in those figures named 'first-order concept'. This first-order concept represents the sub-categories referred to in stage 1 (sub nodes or child nodes). This means that we have created those sub-categories through the references (i.e. parts of the relevant scripts) prior to creating or determining what the main or the parent categories/nodes should be - later referred to as second-order concepts achieved through introducing themes. Also, it is important to understand here that this process was iterative in nature, which means that the authors had to create, recreate or deleted or rename various child and parent nodes depending on what the references indicated each time.

Considering the above, the second stage looked for links between the first-order concepts (Carter 2015) - as mentioned above, those first-order concepts represented the initial categories generated to group ideas and relevant texts within each of the transcripts in the raw data. The first-order concepts were grouped to form second-order themes or concepts aggregated later to form the parent nodes in the NVivo software platform. It is important to note that this inductive process and analysis was carried out in a way that allowed those concepts to be generated by the raw data rather than being purely guided by the study theory or the research question.

\section{Stage 3. Conducting cross-case analysis.}

Stage 3 utilised the information produced in the first two stages - with an iterative process in mind - to look for similarities between the first-order concepts amongst the cases (i.e. cross case analysis - see to Eisenhardt 1989 and Miles and Huberman 1994). A similar analysis was also carried out on the secondorder concepts as well. The intention of this was to combine categories and sub categories (nodes and sub-nodes) together and to achieve an optimum level of parsimonious or abstraction across all cases. Moreover, and as identified in Figure 1, we were able to identify themes in this case which we then 
gathered under what we coined as dimensions in Figure 1 and mechanisms in Figure 2 and those were captured at the highest level of abstraction - it is to be noted that those dimensions and mechanisms correspond to those identified under Petro et al. (2018).

\section{Stage 4. Building/confirming the theoretical framework}

This final stages were confirmatory. To agree on a parsimonious set of constructs as identified by the raw data, the most robust findings were used for this purpose. This stage was also used to introduce further refinements for this study and to kick off any iterative needs.

\section{Stage 5. Inter-rater agreement}

The reliability of each dimension, code or node was assessed with the introduction of a thorough process of checks and reviews by each one of the authors. The naming and the purpose of each of the categories or sub categories generated was challenged in two ways, first of which was with its relevance to the study, and secondly with its meaning and the addition its connotation might have to the literature. The rest of the authors provided an outsider check point. Any disagreements were resolved through discussions, debates and interpretations. All discrepancies were kept on file until a final agreement was achieved. The result of this analysis is presented in Figures 1 and 2. 
Growing knowledge through offered services

Understanding changing client requirements

Working with changing market requirements

Market competitiveness

The generation of scope creep with clients

Failure to understand market requirements
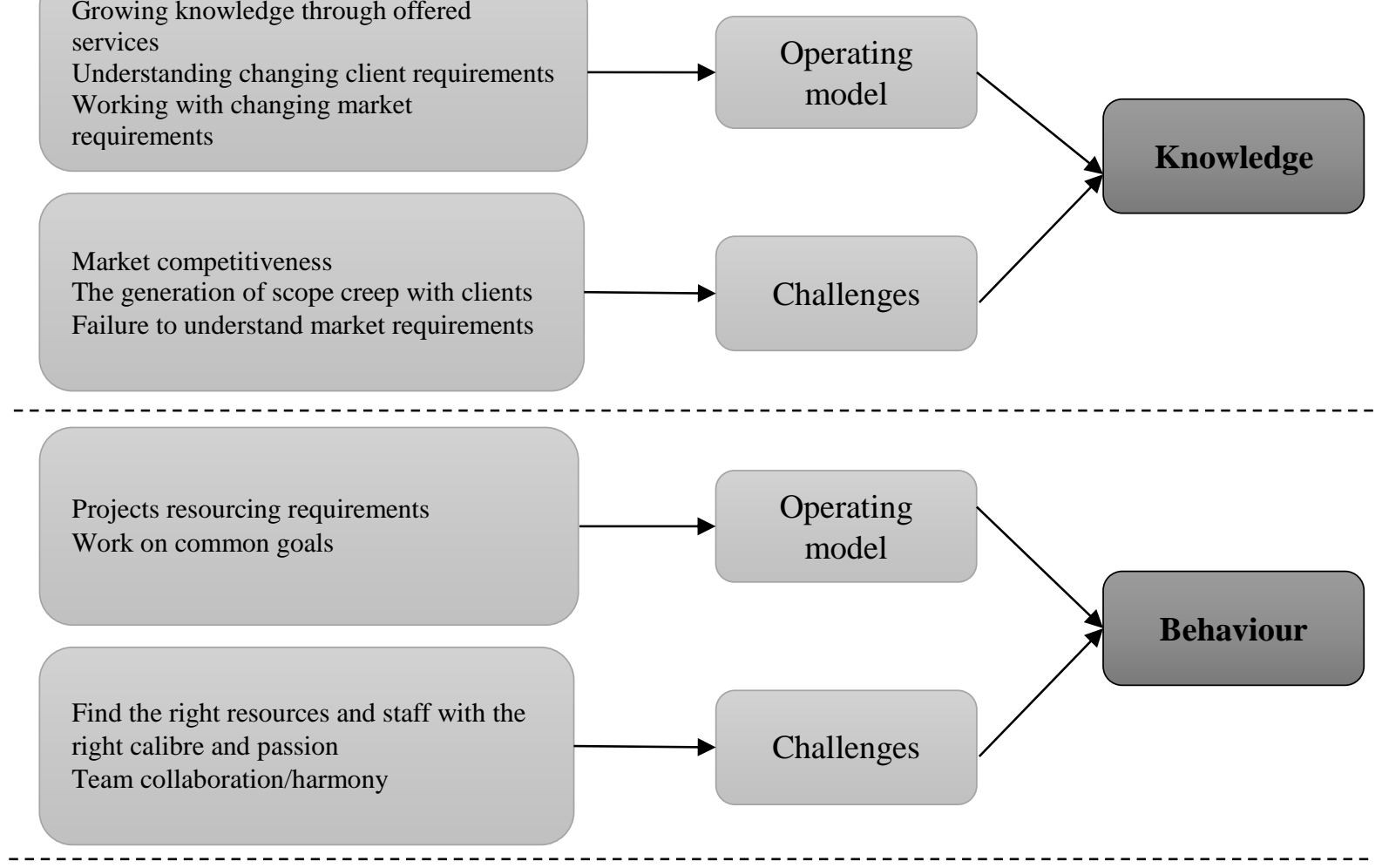

Identify gaps in knowledge/market Internal capabilities

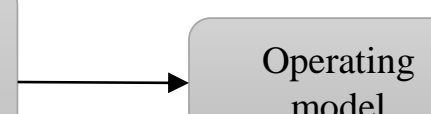

Imlementability of projects

External technology and outsourcing

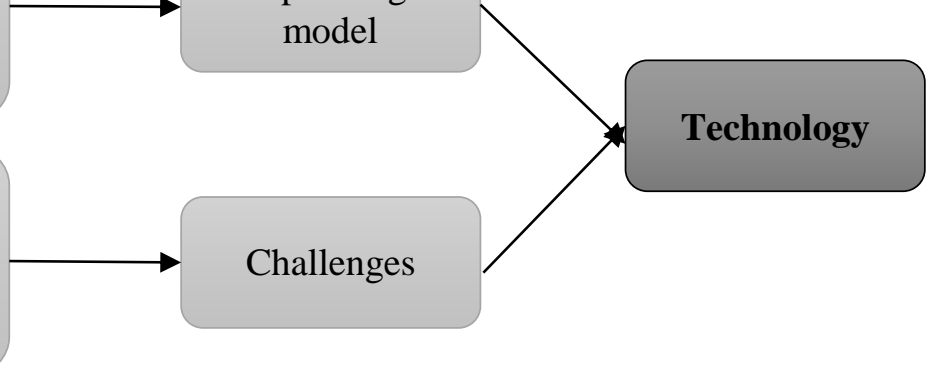

Processes that were needed to grow and sustain ambidexterity

Optimised resource utilisation

Perform simultaneous strategic processes, Market exploration-contacts and clients, Market exploration-balance the portfolio, Invest in innovating new ideas during free time, Regulations

\section{Figure 1: Cross-case analysis for dimensions of ambidexterity}


Flexibility

Alliancing

Roles and responsibilities

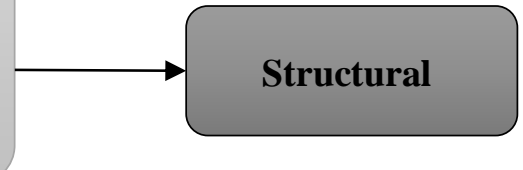

Learn about future directions

Understand what others do

Understand/harness own capabilities

Learn about own projects

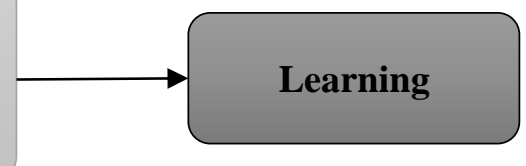

Client's selection

Resources selection

Projects selection

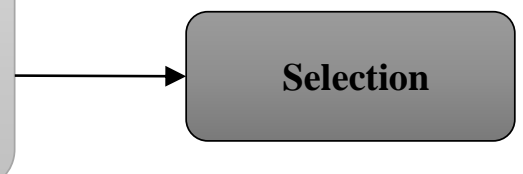

Bond between leader and the team

Internal communications

External communications

External relationships and networks

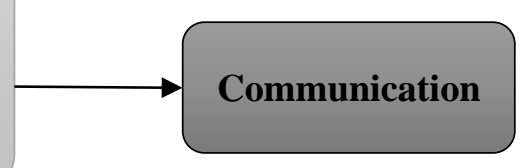

Figure 2: Cross-case analysis for mechanisms of ambidexterity

\section{The findings}

We now report on the findings as relates to the specific dimensions and mechanisms required to achieve project-level ambidexterity and how these dimensions and mechanism are best operationalized at the project level for relevance to project management practice.

\subsection{Dimensions of ambidexterity}

The interviewees reported that their organisations routinely pursued the exploitation and exploration of knowledge, thus suggesting that knowledge may represent a dimension of ambidexterity. The first-order concepts (shown in Figure 1) suggested that there were three main sub-divisions of knowledge (i) 'Growing knowledge through offered services' (ii) 'Understanding changing client requirements' and (iii) 'Working with changing market requirements'.

A number of the interviewees also suggested that market competitiveness constituted one of the challenges that required careful attention as it could work against any of the operating/business model 
identified initially - in particular, the offered services. This suggested the existence of a second dimension of ambidexterity relating to operating/business model which we termed the behaviour dimension. We found 'Projects resourcing requirements' and 'Working on common goals' as the associated first-order concepts. 'Working on common goals'. This set refers to the loyalty of the employees to the organisation. Interviewee 12 refers to his employees and explains how they worked within their own time to resolve issues that arose from the 2009 financial crisis, adding:

"My staff came up with brilliant ideas, such as part-time work and the likes. By them being so loyal to me and to the company and working out of their comfort zone, we managed to survive”.

Challenges as related to the behaviour dimension related to for example the creation of the right conditions to sustain individual learning. Sometimes as Interviewee 11 mentioned, organisational politics served as a barrier against effective individual learning resulting in much tension among employees. The literature (Pinto 2000) alludes to the use of politics and power as having an influence on the success of project implementation, yet most practitioners appear to maintain a negative view of this role.

The findings also suggested the existence of another dimension of ambidexterity which we termed the technological dimension. The literature already suggests that the scalability and adaptability functionality of technology creates an appropriate platform for organisations to pursue ambidextrous initiatives (see Chi et al. 2017). Herein, it was not a surprise that Interviewee 7 identified technology as key to their flexibility noting "a huge demand" for its products, by which they started their application in mass production, infusing efficiency in their operation and creating a fully ambidextrous organisation at the operational level. This view is shared in the literature. For example, Ardichvili et al. (2003) notes that technology offers numerous advantages to firms to create and deliver new opportunities to both existing and future customers. As relates to its operating/business model, the first-order concepts associated with the technological dimension were 'Identify gaps in knowledge/market' and 'Internal capabilities' (shown earlier in Figure 1). In terms of 'Identify gaps in knowledge/market', the emphasis was on the use of technology to for example identify gaps in knowledge about technology within the market. An emphasis on the operating/business model of this dimension could be construed as a form of ambidexterity as the firm in question begin to explore and search for business opportunities utilising technology as a core competency. Commenting on the role of the operating/business model as relating to the technological dimension, Interviewee 12 suggested (within the context of new technological breakthrough in energy savings), that his firm was the:

"...first to see it [and hence] invested in [the] technology". 
In terms of challenges associated with the technological dimension, Interviewee 5 suggested that while technology could represent a key competitive differentiator, it was unclear whether technology could in all circumstances deliver organisational-level or in fact, project-level advantages. Interestingly, this concern has attracted the attention of scholars. Ojiako et al. (2013) had observed that the infusion of technology into service offerings did not necessarily lead to service enhancement.

The final dimension of ambidexterity identified in the study related to what we term the procedural dimension and in terms of its operating/business model, the first-order concepts under this dimension referred to 'Processes that were needed to grow and sustain ambidexterity' and 'Optimised resource utilisation' (shown earlier Figure 1). These processes are as Gibson and Birkinshaw (2004) point out, largely to "...enable and encourage individuals to make their own judgments about how to divide their time between conflicting demands for alignment and adaptability" (p.210). Interviewee 12, for instance, observed that his organisation had endeavoured to expand, but that they found it was

"...spreading itself too thin" due to the lack of proper planning and strategic processes to support such an expansion. Interviewee 7's company's interests on the other hand were to ensure that their processes were robust enough to support their ability to maintain not only their current position in the market, but also seek other opportunities that will guarantee their future competitiveness. Interviewee 5 had concerns on whether their processes were flexible enough to maintain outputs from their current project portfolio while at the same time optimising their project portfolios for the future through enhanced process coordination. In terms of challenges with the processual dimension, for instance, Interviewee 12 noted that his organisation had largely failed to develop processes that exhibited desired strategic flexibility. In his opinion, the leadership of his organisation had found themselves caught in a dilemma: either to support current operations with its well set out processes, or 'overlook' other opportunities (without well set out processes) and therefore loose considerable business leverage potentially emanating from new business opportunities.

\subsection{Mechanisms of ambidexterity}

The first form of ambidexterity mechanism identified from the interviews was structural design. The first-order concepts identified as relevant to this specific mechanism related to 'Flexibility', 'Alliancing', and 'Roles and responsibilities' (shown in Figure 2). In terms of resource 'Flexibility' according to Interviewee 10: 
“...employees wore salesman hats [during the financial crisis] ... and they were all determined to bring in more work to increase their time booking".

Another first-order concept identified as relevant to the structural design mechanism related to 'Alliancing'. The literature on alliancing and project-level ambidexterity is well developed. Herein, drawing from the literature (Das and Teng 2000; Grant and Baden-Fuller 2004; Tiwana 2008), alliances are construed as formal collaborative arrangements between different organisations that have as their objective the creation of strategic and operational value. In this vein, Interviewee 12 suggested that:

"...some of the partnerships my company have engaged in have provided us the exposure and allowed us to expand even further into markets we would otherwise have no access to".

However, continuing in the same vein, Interviewee 12 acknowledged that due to poor project-level integration "...the benefits of some of our partnerships are being questioned by our leadership". Tiwana (2008) opines that an essential operationalisation of alliances is their coordination at the project-level. Without such project-level integration, difficulties are likely to arise as relates to individual alliance partners being able to access the knowledge they require to develop and configure new ideas.

The final first-order concept identified as relevant to the 'structural design' mechanism related to 'Roles and responsibilities'. Literature suggests that a number of factors which includes job and role design can impact upon ambidexterity (Patel et al. 2013). Thus, according to Interviewee 5:

"I am the business development director for the company. I used to be a programmer, then a project manager, and finally got promoted to this position. The company notices talented people and they deal with them with care and grow their talents, which puts them into good positions at the end of the day".

Either way, contribution of individual employees is likely to be enhanced as noted by Interviewee 5 when:

"We ... see what others have achieved as [their] target and then start competing with each other".

In terms of the second form of ambidexterity mechanism, 'learning mechanisms', the first-order concepts that were identified from the study as pertinent to the 'learning mechanisms' included (i) 'Learn about future directions' (ii) 'Understand what others do' (iii) 'Understand/harness own capabilities' and (iv) 
'Learn about own projects' (shown in Figure 2). Interviewee 10, for instance suggested that his organisation had:

"...learn[ed] the hard way".

Brady and Davies (2004) argued that the tendency appears to be that at the initial stage, a new project will be engaged in learning which is predominantly exploratory in nature, signifying the utilisation of new project processes to deal with project activities which are largely unique and hence with, unfamiliar. However, as managers become more familiar with the challenges of the project and settle into a predictable routine, learning increasingly take a more exploitative form drawing from organisation or more specifically, portfolio-level routines. Interviewee 12 had suggested an emphasis within his organisation for "non-traditional" thinking. However, such creative thinking required true commitment and understanding of the current operation and market. Hence:

"We are creative; we always create new things, new processes, new frameworks, and new services".

This point was reiterated by Interviewee 10 when discussing the need for an organisation to understand its business:

“...we moved some operations and resources around to achieve operational efficiency; by doing so, we managed to disperse all their knowledgeable resources across the various company functions and operations".

The third ambidexterity mechanism identified in the study was 'selection mechanisms'. Interviewee 10 informant commented on this point by suggesting that:

"Clients in the Gulf Corporation Council GCC are willing to pay the premium of our services, hence, we locate those clients and work with them".

Project selection within project portfolio management is essential to project portfolio management (Archer and Ghasemzadeh 1999; Fernhaber and Patel, 2012). As earlier alluded to, the selection of the right combination of projects within a portfolio was more than likely to enhance the simultaneous pursuit of multiplicity. Interviewee 8 noted that:

"We sometimes need to chase other types of projects to keep the ball rolling". 
Similarly, Interviewee 5 observed that:

"Our business is divided mainly into two streams, we have the projects operation and we have the retail business; for now, our focus is more on projects not the retail, since the retail business requires lots of infrastructure and preparation and other types of marketing campaigns, which we don't have at the moment. We wish we could be doing better in retail, since it has better DSO and collection system compared to those of projects".

Project selection was is particularly critical according to Interviewee 12 because:

"It is difficult to untangle resources sharing once the projects become operational".

The final mechanisms of ambidexterity which was identified in the findings was 'communication. The first-order concepts in this category refer to (i) 'Bond between leader and the team' (ii) Internal communications (iii) 'External communications' and (iv) 'External relationships and networks' (shown in Figure 2).

The ability of senior executives to communicate with them is an important facet of an ambidextrous organisation and a matter of interest to the literature (García-Granero et al. 2017). Ensuring the simultaneous pursuit of multiplicity requires what Huang et al. (2015) refers to as "communicational ambidexterity", in effect “...the capability to simultaneously address different and often conflicting communication needs that exist in an organization's internal communication, by achieving complementarity between different communication modes" (p. 50). With "communicational ambidexterity", organisations are able to ensure that the different information needs across its different levels are met. It allows according to Interviewee 4 "...the ability of the responsible managers to communicate information which is of both organizational and managerial importance". Such "communicational ambidexterity", according to Interviewee 2, allows for:

"The building of new types of relationships between all stakeholders".

These relationships were best built "...through building long lasting networks and relationships among the various stakeholders" (Interviewee 5).

In sum, the views expressed by the different Interviewee demonstrates that when examining the operating/business model and challenges that the case organisation had to contend with that are imposed by constraints resolvable through ambidexterity, specific dimensions (which are in effect, 
operationalizing constructs) and mechanisms (that is, specific managerial actions) are required to achieve project-level ambidexterity.

\section{Discussions}

The result of the data analysis suggested the existence of specific dimensions and mechanisms of projectlevel ambidexterity likely to be enhanced by project portfolio management practices.

\subsection{Dimensions of ambidexterity}

As relates to dimensions of project-level ambidexterity, the study found the existence of four operationalizing constructs; namely (i) knowledge (ii) behaviour (iii) technology and (iv) process. In terms of the knowledge dimension we had found main knowledge subcategories which appeared mainly exploitative. One such example is 'Growing knowledge through offered services'. The literature suggests that knowledge creation essentially occurs at the interface between projects and the sponsoring organization (Grabher 2004). The sub-divisions of knowledge that emerged from the interviews related to (i) 'Growing knowledge through offered services' (ii) 'Understanding changing client requirements' and (iii) 'Working with changing market requirements'. While all three sub-divisions suggest that focusing on the creation of knowledge at the project level allows for knowledge to be created within the context of how it is to be used, the temporality of projects (see Stjerne and Svejenova 2016; van Marrewijk et al. 2016) means that knowledge created at the project-level could be lost as soon as the project is completed and the project team disperses (Brady and Davies 2004). Arguably, a project portfolio management office (see Unger et al. 2012) can play a major intermediary role here by serving as a repertoire of information. Arguably, for effectiveness, the process of knowledge management may need to be transferred from the project-level to the portfolio level.

Li et al. (2008) claimed that the two constructs of ambidexterity (exploitation and exploration) can be operationalised through distinct knowledge types and perspectives. In terms of perspectives, two are of interest, the first addressing the learning perspective which construes exploitation as knowledge development and exploration as the search for new knowledge and the second focusing on the search perspective which construes exploitation as the local search for knowledge and exploration as the distant search for knowledge. As Khanagha et al. (2014) had pointed out earlier, organisations do not exist in isolation and are expected to interact with a wide variety of suppliers, customers, regulatory bodies and competitors. However, a word of caution as relates to 'Working with changing market requirements' 
from a project portfolio perspective: we opine that organisations that pursue ambidexterity at the project level utilising single projects are unlikely to develop the required competency to address such ambidexterity due to resource constraints. In most cases, resource constraints within single projects imply that the sponsoring organisation will be unable to mobilize the necessary resources required to pursue ambidextrous initiatives within the context of a single project. Utilising project portfolio management practices to support the pursuit ambidexterity at the project level while seemingly attractive is also associated with challenges. First, the new role of project portfolio managers is still evolving, requiring more clarity in terms of their relationship with project managers (Jonas 2010). Second, portfolio managers with declared expertise in exploitative initiatives may not have the required competency to simultaneously manage explorative initiatives (Aubry and Lièvre 2010). Furthermore, it is not unusual for very limited overlap between those that manage individual projects within a portfolio and those with responsibility of the overall management of the portfolio as a whole. In effect, some portfolios may be managed in a manner that entails circumventing any need for resource integration across the individual constituent projects within any given portfolio. Drawing from Stettner and Lavie (2014), there are a number of reasons why this may be desired: one being the desire to maintain specialist project knowledge and routines through specialization, another being the desire to limit possible conflicting between individual projects.

In terms of the second ambidexterity dimension (behaviour), recent studies suggest that the ambidextrous competencies of an organisation may be directly related to individual manager competency for simultaneousity and multiplicity (Aubry and Lièvre 2010). The role of individual managers with the ability to manage specific project and diverse portfolio-wide tasks cannot be underestimated. Similarly, Tempelaar and Rosenkranz (2017) acknowledge not only the importance of the individual level (as a form of agency) in the enactment of ambidexterity citing its key role in driving synergies between exploitation and exploration at the level of the organisation, but also that ambidexterity at the individual level may represent the most challenging to achieve. For one, the knowledge base of most individuals is relatively (compared to organisations) more narrow. More specifically, the literature have shown that when undertaking dynamic and transitionary tasks, ambidextrous behaviour leads to a higher level of performance (Rogan and Mors 2014; Tempelaar and Rosenkranz 2017). Key to the success of such ambidextrous behaviour is not only an ability to overcome the cognitive challenge associated with oscillating (swinging) between multiple and contradictory mind-sets (Rogan and Mors 2014) and roles (Tempelaar and Rosenkranz 2017), but also the self-belief of the individual manager in their ability to succeed in conditions of simultaneousity and multiplicity that characterised ambidexterity. We found 
evidence of organisational politics hampering effective individual learning; yet ambidextrous behaviour is a learning behaviour. Overcoming the barriers to such learning require effective leadership that actively encouraged individual project-level managers to engage in learning that enhanced the knowledge needed to simultaneously exploit current opportunities while at the same time generating new opportunities.

The third ambidexterity dimension that was identified related to technology. The extant literature suggests that technology is an operationalizing construct of ambidexterity. Drawing from Lee et al. (2015), we can conceptualise the ambidexterity dimension of technology as being focused on the organisations ability to simultaneous exploit current and explore new technology resources and practice for what is in effect, contradictory organisational purposes.

Operationalizing ambidexterity through technology also implies simultaneously pursuing technology standardization/scalability (exploitation) and technology flexibility/adaptability (exploration). Mithas and Rust (2016) for example show that technology serves a number of enabling dual performance functions in organisations. For example, technology can simultaneously increase revenues and reduce costs. Technology allows organisations to simultaneously exploit existing opportunities while at the same time searching for new opportunities. Drawing from Chi et al. (2017), we opine that through standardization, organisations are able to reduce relational risks, for example in this case, opportunism on the part of individual projects within a portfolio. However at the same time, technology flexibility (exploration) allows for flexibility in the nature of the contractual relationship between individual projects within a portfolio. Herein, technology ambidexterity can enhance the effectiveness of the relational performance of project portfolios through its combination of various project portfolio governance approaches. As in the case of the behaviour dimension, Mithas and Rust (2016) highlighted the potential risks emenating from a technology dimension of ambidexterity. One such risk is the reality that when an organisation focuses its technology on more than one goal, it creates strategic ambiguity as fit between its technology-led decisions become vaguer. Simultaneously focusing on contradictory technology goals can also prevent the seamless integration of individual projects within the portfolio and at the same time create prioritization challenges.

The final dimension of ambidexterity identified in the study is related to process. Khanagha et al. (2014) had found that the dynamic alternation between separation and integration could be process facilitated. Being the case, there is literature that discusses the role formalized processes play in the achievement of success in projects (Liu et al. 2008). One noted advantage of utilising standard project processes is the ability of the project to exploit economies of scale as the coordination between different processes becomes less complex. Utilising standard project processes also allows for more efficient 
transfer of knowledge across individual constituent projects within a portfolio. This can enhance learning experiences (Teller et al. 2012). Ultimately, the crucial question in project portfolio management process is whether the predictability and control that derives from formalized processes (for example, preventing reckless use of project or portfolio resources) justifies the possible restriction of desired creativity and innovation.

\subsection{Mechanisms of ambidexterity}

Relating to mechanisms of project-level ambidexterity, the study found the existence of four specific managerial actions required to achieve project-level ambidexterity. These are namely (i) structural design (ii) learning (iii) selection and (iv) communication.

A core element of the findings suggests that as relates to structural design, specific concepts that were of interest related to notions such as 'Flexibility', 'Alliancing', and 'Roles and responsibilities'. The literature alludes to organizational ambidexterity while generally a simple to conceptualise, is less than simple to achieve. Flexibility is an important mechanism of ambidexterity because flexibility remains the single core capability that is able to ensure that organisations are agile. Thus, the view that flexibility is a functional capability of organizational ambidexterity (Gibson and Birkinshaw 2004; Raisch et al. 2009; O'Reilly and Tushman 2011). We had earlier identified contextual ambidexterity as the most effective means of actualising ambidexterity at the project level. Generating the flexibility required to support contextual ambidexterity overcomes the need for structural separation - which from the literature (Hoang and Rothaermel 2010) further increases the partitioning (as against the desired integration) of project portfolio activities. Of importance to flexibility of structural design in the use of project portfolios to achieve project-level ambidexterity is that there is the simultaneous use of shared resources (of the portfolio) to engage in exploitation and exploration while at the same time, resource utilisation within individual projects is encouraged and allowed for (Wang and Rafiq 2014).

As relates to the 'learning' which was found to be the second form of ambidexterity, the literature suggests a positive correlation between learning practices and organisational ambidexterity (Lin et al. 2013; Lin and McDonough 2014; Wei et al. 2014). Projects will generally employ different learning

mechanisms to facilitate learning. From the literature it can be assumed that for projects within a portfolio, most learning mechanisms are likely to be focused on enabling the acquisition of knowledge from co-projects within the portfolio via a process of knowledge reconfiguration (Lin et al. 2013; Lin and McDonough 2014). 
A first-order concept that was identified from the study as pertinent to the 'learning mechanisms' included 'Understand what others do'. Inter- portfolio learning is desirable as it ensures that similar knowledge bases are explored. However, one concern with inter- portfolio learning is the likelihood that with the exchange likely focusing on existing knowledge, the exploration of new ideas is less likely. One means of limiting this challenge is to create a culture of open communication at the project portfolio level.

'Selection mechanisms', in effect, project selection and the selection and allocation of project teams in a way that facilitates ambidexterity (Andriopoulos and Lewis 2009; Eriksson 2013), had been identified as the third ambidexterity mechanism. We opine that the relevant literature does not appear contentious. There is general agreement on the advantages of synergies in portfolios, the need to assess strategic fit among projects within a project portfolio and an acknowledgement that such assessment can in the absence of adequate information be particularly challenging (Kornfeld and Kara 2011). The literature acknowledges that the project portfolio selection involves complex quantitative, qualitative and hybrid methods (Dutra et al. 2014). Bessant et al. (2011) had emphasised that the decision on which portfolio to select extends beyond determining the risk associated with the project portfolio to the need for optimised processes. It also extends to selecting an optimised configuration of different project portfolios, taking into consideration for example their different sizes.

Communication had been identified as one of the fourth specific managerial actions (mechanisms) required to achieve project-level ambidexterity. By creating an open environment, individual project managers will become more willing to communicate their experiences and ideas gleaned both from within and outside the boundaries of their individual projects with not only other project managers within the portfolio, but the wider stakeholder group. Arguably, the exchanges that emanate from such an open environment is likely to facilitate much needed collaboration within the wider portfolio, enhancing the effectiveness of resource allocation. Leaning in this sense can be seen as a mechanism for project-level ambidexterity. However, as in the case of knowledge management at the project-level, the temporality of projects creates particular challenges for project-level learning. Hereto, a project portfolio management office can play a major role in capturing and embedding learning experiences from projects and by implication overcoming learning boundaries and divisions in practice which may emerge between projects (Scarbrough et al. 2004).

An interesting perspective that emerges from the study findings relates to possible means of articulating a practical use of PPM practices to achieve ambidexterity. To facilitate such an understanding, reference is made to the possible relationship between PPM practices, as represented by 
tools and techniques, and mechanisms of ambidexterity. This relationship is shown in Table 3 (below) with the tools and techniques drawn primarily from the Project Management Institute (PMI) and the APM (The Chartered Body for the Project Profession).

Table 3. Comparison between mechanisms of ambidexterity and PPM tools and areas

\begin{tabular}{|c|c|c|c|c|}
\hline \multicolumn{2}{|c|}{$\begin{array}{l}\text { Mechanisms of ambidexterity } \\
\text { First- and second-order concepts }\end{array}$} & $\begin{array}{l}\text { PPM tools and techniques } \\
\text { Selection made from PMI }\end{array}$ & $\begin{array}{l}\begin{array}{l}\text { PPM tools and } \\
\text { techniques }\end{array} \\
\text { Selection made from } A P M\end{array}$ & $\begin{array}{l}\text { PPM areas of } \\
\text { management }\end{array}$ \\
\hline \multirow{6}{*}{ 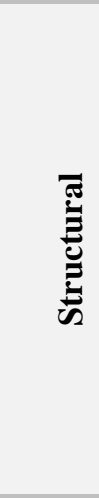 } & \multirow{6}{*}{$\begin{array}{l}\text { Flexibility } \\
\text { Complementary alliances } \\
\text { Roles and responsibilities }\end{array}$} & \multirow{6}{*}{$\begin{array}{l}\text { Portfolio organisational } \\
\text { structure analysis } \\
\text { Projects prioritization } \\
\text { analysis } \\
\text { Portfolio component } \\
\text { categorization }\end{array}$} & Control & \multirow{2}{*}{$\begin{array}{l}\text { Integrative } \\
\text { Management }\end{array}$} \\
\hline & & & Organisation & \\
\hline & & & Change management & Scope Management \\
\hline & & & $\begin{array}{l}\text { Budgeting and cost } \\
\text { control }\end{array}$ & \multirow{3}{*}{$\begin{array}{l}\text { Financial and Cost } \\
\text { Management }\end{array}$} \\
\hline & & & Funding & \\
\hline & & & Investment appeal & \\
\hline \multirow{8}{*}{ : } & \multirow{8}{*}{$\begin{array}{l}\text { Learn about future } \\
\text { directions } \\
\text { Understand what others } \\
\text { do } \\
\text { Understand own } \\
\text { capabilities } \\
\text { Learn about own projects }\end{array}$} & \multirow{8}{*}{$\begin{array}{l}\text { Elicitation techniques } \\
\text { Review meetings } \\
\text { Capacity and capability } \\
\text { analysis }\end{array}$} & Business case & $\begin{array}{l}\text { Integrative } \\
\text { Management }\end{array}$ \\
\hline & & & $\begin{array}{l}\text { Configuration } \\
\text { management }\end{array}$ & \multirow{3}{*}{ Scope Management } \\
\hline & & & $\begin{array}{l}\text { Requirements } \\
\text { management }\end{array}$ & \\
\hline & & & Solutions development & \\
\hline & & & Resource scheduling & $\begin{array}{l}\text { Schedule } \\
\text { Management }\end{array}$ \\
\hline & & & Risk techniques & Risk Management \\
\hline & & & Assurance & Quality \\
\hline & & & Reviews & Management \\
\hline \multirow{7}{*}{$\frac{\Xi}{\stackrel{0}{\varrho}}$} & \multirow[t]{2}{*}{ Clients selection } & \multirow{7}{*}{$\begin{array}{l}\text { Capacity and capability } \\
\text { analysis } \\
\text { Qualitative and quantitative } \\
\text { analysis } \\
\text { Projects prioritization } \\
\text { analysis } \\
\text { Portfolio component } \\
\text { categorization }\end{array}$} & Benefits management & \multirow{2}{*}{ Scope Management } \\
\hline & & & Solutions development & \\
\hline & \multirow[t]{5}{*}{ Projects selection } & & Resource scheduling & \multirow{2}{*}{$\begin{array}{l}\text { Schedule } \\
\text { Management }\end{array}$} \\
\hline & & & Time scheduling & \\
\hline & & & $\begin{array}{l}\text { Budgeting and cost } \\
\text { control }\end{array}$ & \multirow{3}{*}{$\begin{array}{l}\text { Financial and Cost } \\
\text { Management }\end{array}$} \\
\hline & & & Funding & \\
\hline & & & Investment appeal & \\
\hline
\end{tabular}




\begin{tabular}{|c|c|c|c|c|}
\hline & & & Contract & \\
\hline & & & Mobilization & \\
\hline & & & Procurement & \\
\hline & & & $\begin{array}{l}\text { Provider selection and } \\
\text { management }\end{array}$ & $\begin{array}{l}\text { Resource } \\
\text { Management }\end{array}$ \\
\hline \multirow{9}{*}{ 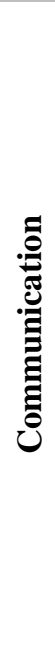 } & \multirow{9}{*}{$\begin{array}{l}\text { Bond between the leader } \\
\text { and the team } \\
\text { Internal communications } \\
\text { External communications } \\
\text { External relationships and } \\
\text { networks }\end{array}$} & \multirow{2}{*}{$\begin{array}{l}\text { Communication methods } \\
\text { Communication analysis }\end{array}$} & Information management & \multirow{3}{*}{$\begin{array}{l}\text { Integrative } \\
\text { Management }\end{array}$} \\
\hline & & & Planning & \\
\hline & & \multirow{7}{*}{$\begin{array}{l}\text { Stakeholder analysis } \\
\text { Elicitation techniques }\end{array}$} & Stakeholder management & \\
\hline & & & Change control & \multirow[t]{2}{*}{ Scope Management } \\
\hline & & & Change management & \\
\hline & & & Risk context & \multirow{2}{*}{ Risk Management } \\
\hline & & & Risk techniques & \\
\hline & & & Assurance & \multirow{2}{*}{$\begin{array}{l}\text { Quality } \\
\text { Management }\end{array}$} \\
\hline & & & Reviews & \\
\hline
\end{tabular}

The APM (APM, 2012) for example divides the knowledge behind managing the portfolio into seven areas of management which are shown in the last column of Table 3. Each of these knowledge areas can be compared and mapped against the mechanisms of ambidexterity (structural, learning, selection, and communication) represented by their first-order concepts, as presented in the first columns. Project portfolio management (PPM) practices within each of the management areas, as presented in the penultimate column, are applied as part of the portfolio management (discussed below). The middle column of Table 3 shows a similar analysis using PMI tools and techniques. There are numerous professional project management bodies of knowledge in circulation (Morris et al. 2006). However, we focus on the PMI and the APM because both organisations command arguably the most members and by implication, their PPM bodies of knowledge, encapsulated for example in the case of the PMI in the Standard for Portfolio Management (PMI, 2013) represent the most influential and widely adopted PPM practitioner manuals in circulation.

The first three columns of Table 3 provide a comparative analysis between the first- and the second-order concepts of mechanisms of ambidexterity, along with a selection of PPM practices.

Firstly, the 'structural' mechanisms used for achieving ambidexterity have been divided in this qualitative analysis into three first-order concepts/components: 'flexibility', 'complementary alliances', 
and 'roles and responsibilities'. The portfolio structural analysis refers to the assignment of roles and responsibilities of the portfolio; this goes with the needed structural, size, and complexity analysis of the organisation and the size of the projects in hand. These resemble the structural mechanisms of achieving ambidexterity. Resources are explored at this juncture and analysed, along with the rest of the portfolio components. This is in order to build a comprehensive structuring plan that allows for their feasibility of use and ease of application. Moreover, these tools and techniques define the structure of the portfolio and link this to the structure of the organisation; this structure then defines the needed roles and responsibilities to run the organisation and its portfolios. These tools may generate the need to separate exploratory activities from those that are exploitative to form a temporal separation, a domain separation, or a structural separation. Prioritization of projects can be introduced to support the organisational structure; this can be accompanied with scenario analysis and categorization. A clear demarcation between organic and mechanistic structures can also be identified here.

The second, 'learning' mechanisms used for achieving ambidexterity have been divided in this qualitative analysis into four first-order concepts/components: learn about future directions, understand what others do, understand own capabilities and learn about own projects. Elicitation techniques here refer to planning, setting up metrics, understanding the direction of the business, measuring the performance, and re-strategizing when and as needed (PMI 2013). These are all accompanied with the review meetings, steering committee meetings, and performance review meetings required to set the target and move toward the strategized direction. Capability and capacity analysis refers to the analysis of resources, their (resources) schedules, funding requirements, and any other relevant resources or capabilities needed to deliver the portfolio (PMI 2013). This is where the PPM manager learns the different requirements for the portfolio through brainstorming, facilitation, surveys, learning from, and collaborating with others, such as in work groups and with internal or external experts, alliances, the client, and/or stakeholders. It is assumed that the PPM manager has absolute control over all the resources within the organisation, however; this may not be the case, particularly in less mature organisations. PPM perceived control, or the lack of it, may therefore have an effect on the efforts expended in building and achieving ambidexterity.

Third, 'selection' mechanisms used for achieving ambidexterity have been divided in this qualitative analysis into three first-order concepts/components: clients selection, resources selection, and projects selection. Portfolio management tools and techniques selected under this component for comparison with mechanisms refer to capacity and capability analysis, projects prioritization analysis, and portfolio component categorization, as discussed earlier. Although most of these tools and techniques 
have been referred to under other mechanisms, they still can work under these mechanisms. It is to be noted that it was never the intention here to set a clear-cut demarcation between components, mechanisms, and/or tools and techniques. The qualitative and quantitative analyses, in this case, tap into the capability and capacity assessment specifically for resources with the intention to improve their schedules for the betterment of the entire portfolio and the organisation.

Finally, 'communication' mechanisms used for achieving ambidexterity have been divided in this qualitative analysis into four first-order concepts/components: bond between the leader and the team, internal communications, external communications, and external relationships and networks. The PPM tools and techniques compare with many components under this category. Stakeholder analysis, for instance, defines those stakeholders that need to be satisfied or appeased, the methods of communication and analysis with stakeholders and others, and the elicitation techniques, as discussed above. The use of various communication and information transfer techniques can help generate ambidexterity when exposed to those appropriate techniques, as mentioned above.

\section{Conclusions}

The study commenced on the notion that while there is a paucity of research explicitly situated within the context of projects, the concept of ambidexterity is of theoretical and practical value to the discipline of project management. Notably, the transient nature and mutuality of interdependencies that exist within projects have made them ideally suitable for catering for ambidexterity's contradictory constructs; exploitation and exploration. While projects are used by organisations to operationalize their visions, organisations rarely pursue single projects, due to declining returns, most organisations implement numerous projects (simultaneously), in the form of 'project portfolios'. The question however that becomes of interest is how project portfolio management (PPM) can facilitate ambidexterity in projectbased organisations and more specifically, what specific dimensions (specific project-based attributes that are capable of creating paradoxes) and mechanisms (managerial actions) required to achieve such level of ambidexterity. The paper draws particularly on alliance theory which provides the necessary foundations that explains how PPM can facilitate ambidexterity through inter-project connections that exist within and across portfolio boundaries. It is observed that projects within portfolios can enhance and complement the ambidextrous competencies of other co-projects. Thus, exploring ambidexterity from the point of an inter-project alliance (portfolio), it was noted that such portfolios serve as importance facilitators for ambidexterity in that they allow individual projects simultaneously focus on existing and new initiatives. 
To explore the question, this paper reported on the outcome of a three-year study which culminated with a multiple exploratory interviews of senior executives involved in project-level activities who were drawn from twelve case organisations in the Middle East. These dimensions and mechanisms which represented a prism for exploring project-level ambidexterity, had emerged from earlier taxonomical analysis of the elements and components of ambidexterity (see Petro et al. 2018) representing a prism for exploring project-level ambidexterity. For management and practitioner relevance, interviewees were drawn from 'senior executives (managers) whose relevance to ambidexterity is drawn from the literature due to their frontline operational roles as contemplated by Zimmermann et al. (2018). The outcomes of the interviews were analysed utilising a five-stage systematic analytical process. Based on the advanced research question, specific dimensions and mechanisms of project-level ambidexterity likely to be enhanced by PPM practices were identified. In terms of dimensions, the study found the existence of four operationalizing constructs of project-level ambidexterity; namely (i) knowledge (ii) behaviour (iii) technology and (iv) process. On the other hand, in terms of mechanisms, four specific managerial actions required to achieve project-level ambidexterity were identified as (i) structural design (ii) learning (iii) selection and (iv) communication.

This study makes specific practical and theoretical contributions. In terms of practical relevance, it has provided new means and measures that can be used to assess gaps in organisations, with a particular focus on Project Based Organisations; it facilitates the identification of those gaps by linking them to the definition of dimensions and mechanisms of ambidexterity. A reflection of the practicalities associated with PPM practices was drawn based on existing bodies of knowledge derived from the Project Management Institute (PMI) and the APM (The Chartered Body for the Project Profession). On this basis, the authors argue that an appreciation of the interplay between the dimensions and mechanisms of PPM-facilitated ambidexterity is required to mitigate against potential risk of ambiguity arising between the various stakeholders involved in PPM delivery. In effect, an appreciation of these dimensions and mechanisms is likely to enhance successful project delivery. However, analysing the conclusions that flows from the study, following the practitioner discourse (laid out in Table 3), there is a viable suggestion that due to the nature of the operating/business model and challenges that organisations have to contend with, the dimensions and mechanisms needed to achieve ambidexterity in project-based organisations need may actually require further and meaningful simplification in order to accommodate differences between individual projects. The reason for this position is that comparison shown in Table 3 raises questions on whether managers are able to comprehend the nature of the challenges associated with facilitating ambidexterity through PPM. In acknowledging that that projects are unlikely to be 
explicitly exploitative or exploratory in nature (Sohani and Singh 2017), congruence remains a matter of critical importance to projects. Finally, these developments within the concept of ambidexterity, combined with the alignment with PPM practices above, helps practitioners and managers comprehend the importance and influence of this dynamic capability on Project-Based Organisations, particularly when placed in complex and dynamic environments.

As relates to theoretical contributions, this study firstly directly responds to the increased demands for empirical based studies in operations and project management. Secondly, the study draws upon such empirical evidence to elaborate on not only the specific dimensions and mechanisms required to achieve project-level ambidexterity, but also on their operationalization.

As expected, the study is not without limitations associated with case study research (Ketokivi and Choi 2014). In particular, the study was exploratory rather than quantitative and further research could, based on the framework developed within this study, carry out more statistical study to validate the conclusions. Such work could use a similar methodology to the well-known Jansen et al (2012) in looking at the ambidexterity in individual units within a larger enterprise and the performance implications, showing how the underlying features of the enterprise act as an important "boundary condition" for the analysis. Indeed, more work towards quantifying these features of project-oriented organisations may allow the application of the Theory of Constraints (a management philosophy focusing on the "weakest links" to improve system performance) towards optimising the organisational choices (see Simsit et al 2014).

Furthermore, although projects due to their temporal nature are inherently political in nature, the study made no effort to explore the existence of possible temporal interests how their existence may shape the interpretation of ambidexterity. Earlier studies by McGivern et al. (2017) suggests that the interpretation of task frames in projects are usually of a temporal nature. It may be of interest to further studies to explore whether (and possibly how), political dynamics are able to manipulate the generation of a temporal conception of ambidexterity. Another key limitation of the study related to the framing of project-level ambidexterity. Recent literature (Zimmermann et al. 2018) now alludes to (i) ambidexterity neither being a linear process that encapsulates the straightforward emergence of appropriate coping designs once the approach is adopted and (ii) that exploitation and exploration tensions although they can be temporarily inoperative, always linger on and reappear. In effect, ambidexterity is never a static phase, instead it is a process in a state constant flux. Both positions suggest that there is a need for continuous reshaping of PPM initiatives to be able to cater for what is in effect a constantly evolving tension between exploitation and exploration. However, although being the case, the constant nature of 
this evolving tensions were not catered for in the study. Accordingly, there is an opportunity to explore in future studies the nature and operationalization of specific dynamic dimensions and required to achieve project-level ambidexterity.

\section{References}

Adler, P., Goldoftas, B., and Levine, D. 1999. "Flexibility versus efficiency: A case study of model changeovers in the Toyota production system." Organization Science 10: 43-68.

Andriopoulos, C., and Lewis, M. 2009. "Exploitation-exploration tensions and organizational ambidexterity: Managing paradoxes of innovation.” Organization Science 20(4): 696-717.

Association for Project Management (APM). 2012. APM Body of Knowledge, 6th ed. Cambridge, UK: Association for Project Management.

Archer, N., and Ghasemzadeh, F. 1999. "An integrated framework for project portfolio selection." International Journal of Project Management 17(4): 207-216.

Ardichvili, A., Cardozo, R., and Ray, S. 2003. "A theory of entrepreneurial opportunity identification and development." Journal of Business Venturing 18(1): 105-123.

Aubry, M., and Lièvre, P. 2010. "Ambidexterity as a competence of project leaders: A case study from two polar expeditions." Project Management Journal 41(3): 32-44.

Bamberger, P., and Meshoulam, I. 2000. Human resource strategy. Newbury Park, CA: Sage

Baron, J. and Bielby, W. 1986. "The proliferation of job titles in organizations." Administrative Science Quarterly 31 (4): 561-586.

Beckman, C., 2006. "The influence of founding team company affiliations on firm behaviour." Academy of Management Journal 49(4): 741-758.

Bierly, P., and Gallagher, S. 2007. "Explaining alliance partner selection: fit, trust and strategic expediency." Long Range Planning 40(2): 134-153.

Bessant, J., Von Stamm, B., and Moeslein, K. 2011. "Selection strategies for discontinuous innovation." International Journal of Technology Management 55(1/2): 156-170.

Beverland, M., Wilner, S., and Micheli, P. 2015. "Reconciling the tension between consistency and relevance: design thinking as a mechanism for brand ambidexterity." Journal of the Academy of Marketing Science 43(5): 589-609.

Birkinshaw, J., and Gupta, K. 2013. "Clarifying the distinctive contribution of ambidexterity to the field of organization studies." Academy of Management Perspectives 27(4): 287-298.

Birkinshaw, J., Zimmermann, A., and Raisch, S. 2016. "How do firms adapt to discontinuous change? Bridging the dynamic capabilities and ambidexterity perspectives." California Management Review 58 (4): 36-58.

Blomquist, T., Hällgren, M., Nilsson, A., and Söderholm, A. 2010. "Project-as-practice: In search of project management research that matters." Project Management Journal 41(1): 5-16.

Brady, T., and Davies, A. 2004. "Building project capabilities: from exploratory to exploitative learning." Organization Studies 25(9): 1601-1621.

Bresciani, S., Ferraris, A., and Del Giudice, M. 2017. "The management of organizational ambidexterity through alliances in a new context of analysis: Internet of Things (IoT) smart city projects." Technological Forecasting and Social Change DOI: https://doi.org/10.1016/j.techfore.2017.03.002

Cao, Q., Gedajlovic, E., and Zhang, H. 2009. "Unpacking organizational ambidexterity: Dimensions, contingencies, and synergistic effects." Organization Science 20(4): 781-796.

Cantarello, S., Martini, A., and Nosella, A. 2012. "A multi-level model for organizational ambidexterity in the search phase of the innovation process. Creativity and Innovation Management 21(1): 28-48. 
Carter, W. 2015. "Ambidexterity deconstructed: a hierarchy of capabilities perspective. Management Research Review 38(8): 794-812.

Chi, M., Zhao, J., George, J., Li, Y., and Zhai, S. 2017. "The influence of inter-firm IT governance strategies on relational performance: The moderation effect of information technology ambidexterity." International Journal of Information Management 37(2): 43-53.

Chipulu, M., Ojiako, U., Gardiner, P., Williams, T., Mota, C., Maguire, S., Shou, Y., Stamati, T. and Marshall, A. 2014. "Exploring the impact of cultural values on project performance: The effects of cultural values, age and gender on the perceived importance of project success/failure factors." International Journal of Operations \& Production Management 34(3): 364-389.

Chipulu, M., Ojiako, U., Marshall, A., Williams, T., Bititci, U., Mota, C., Shou, Y., Thomas, A., El Dirani, A., Maguire, S., \& Stamati, T. (2019). A dimensional analysis of stakeholder assessment of project outcomes, Production Planning \& Control, In Press.

Choi, T., Cheng, T., and Zhao, X. 2016. "Multi-methodological research in operations management." Production and Operations Management 25(3): 379-389.

Cicmil, S., Williams, T., Thomas, J., and Hodgson, D. 2006. "Rethinking project management: researching the actuality of projects." International Journal of Project Management 24(8): 675-686.

Currall, S., Hammer, T., Baggeit, L., and Doniger, G. 2015. "Combining qualitative and quantitative methodologies to study group processes: An illustrative study of a corporate board of directors." Organizational Research Methods 2(1): 5-36.

Das, T., and Teng, B. 2000. "A resource-based theory of strategic alliances." Journal of Management 26(1): 31-61.

Davies, A., and Brady, T. 2016. "Explicating the dynamics of project capabilities." International Journal of Project Management 34(2): 314-327.

Dearden, J. 1972. "MIS is a mirage." Harvard Business Review 50(1): 90-99.

Du, W., Pan, S., and Zuo, M. 2013. "How to balance sustainability and profitability in technology organizations: An ambidextrous perspective." IEEE Transactions on Engineering Management 60(2): 366-385.

Dutra, C., Ribeiro, J. and de Carvalho, M. 2014. "An economic-probabilistic model for project selection and prioritization." International Journal of Project Management 32(6): 1042-1055.

Eisenhardt, K. 1989. "Building theories from case study research." Academy of Management Review, 14(4): 532-550.

Eisenhardt, K., and Graebner, M. 2007. "Theory building from cases: Opportunities and challenges." Academy of Management Journal 50(1): 25-32.

Eriksson, P., 2013. "Exploration and exploitation in project-based organizations: Development and diffusion of knowledge at different organizational levels in construction companies." International Journal of Project Management 31(3): 333-341.

Esposito De Falco, S., Renzi, A., Orlando, B., and Cucari, N. 2017. "Open collaborative innovation and digital platforms." Production Planning \& Control 28(16): 1344-1353

Essex, A., Subramanian, N., and Gunasekaran, A. 2016. "The relationship between supply chain manager capabilities and performance: empirical evidence.” Production Planning \& Control 27(3): 198-211.

Fernhaber, S. and Patel, P. 2012. "How do young firms manage product portfolio complexity? The role of absorptive capacity and ambidexterity." Strategic Management Journal 33(13): 1516-1539.

Filippini, R., Güttel, W., and Nosella, A. 2012. "Ambidexterity and the evolution of knowledge management initiatives." Journal of Business Research 65(3): 317-324.

Fink, A., 2010. Conducting Research Literature Reviews: From the Internet to Paper, 3rd ed. Sage, Thousand Oaks.

Foray, D., and Grübler, A. 1996. "Technology and the environment: an overview." Technological Forecasting and Social Change 53(1): 3-13. 
Gaiardelli, P., Martinez, V., and Cavalieri, S. 2015. "The strategic transition to services: a dominant logic perspective and its implications for operations." Production Planning \& Control 26(14-15): 11651170.

García-Granero, A., Fernández-Mesa, A., Jansen, J., and Vega-Jurado, J. 2017. "Top management team diversity and ambidexterity: The contingent role of shared responsibility and CEO cognitive trust." Long Range Planning DOI: https://doi.org/10.1016/j.lrp.2017.11.001.

Geerts, A., Leten, B., Belderbos, R., and Van Looy, B., 2018. "Does spatial ambidexterity pay off? On the benefits of geographic proximity between technology exploitation and exploration." Journal of Product Innovation Management 35(2): 151-163.

Geraldi, J., and Söderlund, J., 2018. "Project studies: What it is, where it is going." International Journal of Project Management 36(1): 55-70.

Gerwin, D., and Ferris, J. 2004. "Organizing new product development projects in strategic alliances." Organization Science 15(1):22-37.

Gherardi, S., and Strati, A. 1988. "The temporal dimension in organizational studies." Organization Science 9(2): 149-164.

Gibson, C., and Birkinshaw, J. 2004. "The antecedents, consequences, and mediating role of organizational ambidexterity." Academy of Management Journal 47: 209-226.

Grabher, G. 2004. Temporary Architectures of Learning: Knowledge Governance in Project Ecologies. Organization Studies 25 (9):1491-1514.

Grant, K., and Pennypacker, J. 2006. "Project management maturity: an assessment of project management capabilities among and between selected industries." IEEE Transactions on Engineering Management 53(1): 59-68.

Grant, R. and Baden-Fuller, C. 2004. "A knowledge accessing theory of strategic alliances." Journal of Management Studies 41(1): 61-84.

Hayes, R. 2002. "Challenges posed to operations management by the "new economy". Production and Operations Management 11(1): 21-32.

He, Z., and Wong, P. 2004. "Exploration and exploitation: An empirical test of the ambidextrous hypothesis." Organization Science 15: 481-496.

Hoang, H., and Rothaermel, F. 2010. "Leveraging internal and external experience: exploration, exploitation, and R\&D project performance." Strategic Management Journal 31(7): 734-758.

Huang, J., Baptista, J. and Newell, S. 2015. "Communicational ambidexterity as a new capability to manage social media communication within organizations." Journal of Strategic Information Systems 24(2): 49-64.

Im, G. and Rai, A. 2008. "Knowledge sharing ambidexterity in long-term interorganizational relationships." Management Science 54(7): 1281-1296.

Jansen, J., Simsek, Z. and Cao, Q., 2012. "Ambidexterity and performance in multiunit contexts: Crosslevel moderating effects of structural and resource attributes". Strategic Management Journal, 33(11): 1286-1303.

Jansen, J., Van den Bosch, F. and Volberda, H. 2005. "Exploratory innovation, exploitative innovation, and ambidexterity: The impact of environmental and organizational antecedents." Schmalenbach Business Review 57(4): 351-363.

Jansen, J., Tempelaar, M., Van den Bosch, F., and Volberda, H. 2009. "Structural differentiation and ambidexterity: The mediating role of integration mechanisms." Organization Science 20(4): 797811.

Jonas, D. 2010. "Empowering project portfolio managers: How management involvement impacts project portfolio management performance." International Journal of Project Management 28(8): 818-831. 
Julian, J. 2008. "How project management office leaders facilitate cross-project learning and continuous improvement." Project Management Journal 39(3): 43-58.

Kane, G., and Alavi, M. 2007. "Information technology and organizational learning: An investigation of exploration and exploitation processes." Organization Science 18(5): 796-812.

Kassotaki, O., Paroutis, S. and Morrell, K. 2018. "Ambidexterity penetration across multiple organizational levels in an aerospace and defense organization." Long Range Planning DOI: https://doi.org/10.1016/j.lrp.2018.06.002.

Kathuria, A., and Konsynski, B. 2012. Juggling Paradoxical Strategies: The Emergent Role of IT Capabilities. Proceedings of the 33rd International Conference on Information Systems (ICIS), Orlando, FL: Association for Information Systems.

Ketokivi, M. and Choi, T. 2014. "Renaissance of case research as a scientific method." Journal of Operations Management 32(5):232-240.

Khanagha, S., Volberda, H., and Oshri, I. 2014. "Business model renewal and ambidexterity: structural alteration and strategy formation process during transition to a Cloud business model." $R \& D$ Management 44(3): 322-340.

Kock, A., Heising, W. and Gemünden, H. 2015. "How ideation portfolio management influences frontend success." Journal of Product Innovation Management 32(4):539-555.

Kopmann, J., Kock, A., Killen, C. and Gemünden, H. 2017. "The role of project portfolio management in fostering both deliberate and emergent strategy." International Journal of Project Management 35(4):557-570.

Kornfeld, B. and Kara, S. 2011. "Project portfolio selection in continuous improvement." International Journal of Operations \& Production Management 31(10): 1071-1088.

Kortmann, S., Gelhard, C., Zimmermann, C. and Piller, F. 2014. "Linking strategic flexibility and operational efficiency: The mediating role of ambidextrous operational capabilities." Journal of Operations Management 32(7-8):475-490.

Kozinets, R. 2002. "The field behind the screen: Using netnography for marketing research in online communities." Journal of Marketing Research 39(1):61-72.

Lavie, D., and Rosenkopf, R. 2006. "Balancing exploration and exploitation in alliance formation." Academy of Management Journal 49(4): 797-818.

Lee, G., DeLone, W., and Espinosa, J. 2006. Ambidextrous coping strategies in globally distributed software development projects." Communications of the ACM 49(10): 35-40.

Lee, O., Sambamurthy, V., Lim, K. and Wei, K. 2015. "How does IT ambidexterity impact organizational agility?.” Information Systems Research 26(2):398-417.

Leonard-Barton, D. 1992. "Core capabilities and core rigidities: A paradox in managing new product development.” Strategic Management Journal 13(S1): pp.111-125.

Leybourne, S., and Sainter, P. 2012. "Advancing project management: Authenticating the shift from process to nuanced project-based management in the ambidextrous organization." Project Management Journal 43(6): 5-15.

Li, Y., Vanhaverbeke, W. and Schoenmakers, W. 2008. "Exploration and exploitation in innovation: Reframing the interpretation." Creativity and Innovation Management 17(2): 107-126

Lin, $\mathrm{H}$ and McDonough, E. 2011. "Investigating the role of leadership and organizational culture in fostering innovation ambidexterity." IEEE Transactions on Engineering Management 58: 497-509.

Lin, H., McDonough, E., Lin, S. and Lin, C. 2013. "Managing the exploitation/exploration paradox: The role of a learning capability and innovation ambidexterity." Journal of Product Innovation Management 30(2): 262-278.

Lin, H. and McDonough, E. 2014. "Cognitive frames, learning mechanisms, and innovation ambidexterity.” Journal of Product Innovation Management 31(S1):170-188. 
Liu, L., and Leitner, D. 2012. "Simultaneous pursuit of innovation and efficiency in complex engineering projects: A study of the antecedents and impacts of ambidexterity in project teams." Project Management Journal 43(6): 97-110.

Liu, J., Chen, V., Chan, C. and Lie, T. 2008. "The impact of software process standardization on software flexibility and project management performance: Control theory perspective." Information and Software Technology 50(9-10): 889-896.

Liu, L., Wang, X. and Sheng, Z. 2012. "Achieving ambidexterity in large, complex engineering projects: a case study of the Sutong Bridge project." Construction Management and Economics 30(5):399409.

Love, P., Smith, J., Ackermann, F. and Irani, Z. 2018. "The praxis of stupidity: an explanation to understand the barriers mitigating rework in construction." Production Planning \& Control 29 (13): 1112-1125.

Malach-Pines, A., Dvir, D. and Sadeh, A. 2009. "Project manager-project (PM-P) fit and project success.” International Journal of Operations \& Production Management 29(3):268-291.

Martinsuo, M., 2013. Project portfolio management in practice and in context. International Journal of Project Management 31(6): 794-803.

Miles, M., and Huberman, A. 1994. Qualitative data analysis: An expanded sourcebook. Pub. Sage.

Montuori, A. (2005). "Literature review as creative inquiry: Reframing scholarship as a creative process." Journal of Transformative Education 3(4): 374-393.

Marshall, A. and Ojiako, U. 2013. "Managing Risk through the Veil of Ignorance." Journal of Risk Research 16 (10): 1225-1239.

Marshall, A., Ojiako, U., Wang, V., Lin, F., and Chipulu, M. 2019. "Forecasting Unknown/Unknowns by Boosting the Risk Radar within the Risk Intelligent Organisation." International Journal of Forecasting https://doi.org/10.1016/j.ijforecast.2018.07.015.

Matthews, R., Tan, K., and Marzec, P. 2015. "Organizational ambidexterity within process improvement." Journal of Manufacturing Technology Management 26(4): 458-476.

Maylor, H., Meredith, J., Söderlund, J. and Browning, T. 2018. "Old theories, new contexts: extending operations management theories to projects." International Journal of Operations \& Production Management 38(6): 1274-1288.

McGivern, G., Dopson, S., Ferlie, E., Fischer, M., Fitzgerald, L., Ledger, J. and Bennett, C. 2017. "The silent politics of temporal work: A case study of a management consultancy project to redesign public health care." Organization Studies DOI: 0170840617708004.

McKenna, E. 2006. Business psychology and organizational behaviour. Hove: Psychology Press.

Mead, G. 1938. The Philosophy of the Act. University of Chicago Press.

Mero-Jaffe, I. 2011. 'Is that what I said?' Interview transcript approval by participants: An aspect of ethics in qualitative research." International Journal of Qualitative Methods 10(3):231-247.

Mishra, A., Chandrasekaran, A. and MacCormack, A. 2015. "Collaboration in Multi-Partner R\&D projects: The impact of partnering scale and scope." Journal of Operations Management 33/34: 114.

Mishra, A. and Sinha, K. 2016. "Work design and integration glitches in globally distributed technology projects." Production and Operations Management 25(2):347-369.

Mithas, S. and Rust, R. 2016. "How Information Technology Strategy and Investments Influence Firm Performance: Conjecture and Empirical Evidence. MIS Quarterly 40 (1): 223-245.

Mom, T., Bosch, F., and Volberda, H. 2007. "Investigating managers' exploration and exploitation activities: The influence of to-down, bottom-up, and horizontal knowledge flow." Journal of Management Studies 44(6): 910 - 931. 
Mom, T., Van Den Bosch, F. and Volberda, H. 2009. 'Understanding variation in managers' ambidexterity: Investigating direct and interaction effects of formal structural and personal coordination mechanisms." Organization Science 20(4):812-828.

Morris, P., Crawford, L., Hodgson, D., Shepherd, M., and Thomas, J. 2006. "Exploring the role of formal bodies of knowledge in defining a profession-The case of project management." International Journal of Project Management 24(8):710-721.

Novick, G. 2008. "Is there a bias against telephone interviews in qualitative research?" Research in Nursing \& Health 31(4):391-398.

O'Reilly, C. and Tushman, M. 2011. "Organizational ambidexterity in action: How managers explore and exploit." California Management Review 53(4):5-22.

Obstfeld, D. 2012. "Creative projects: A less routine approach toward getting new things done." Organization Science 23(6):1571-1592.

Oehmichen, J., Heyden, M.L., Georgakakis, D. and Volberda, H. 2017. "Boards of directors and organizational ambidexterity in knowledge-intensive firms." International Journal of Human Resource Management 28(2): 283-306.

Ojiako, U., Maguire, S., and Chipulu, M. 2013. "Thematic elements underlying the delivery of services in high-contact public service encounters." Production Planning and Control 24 (6): 532-545.

Ojiako, U., Chipulu, M., Marshall, A., Ashleigh, M., Maguire, S., Williams, T. and Obokoh, L. $2015 a$. "Heterogeneity and perception congruence of project outcomes." Production Planning \& Control 26(11):858-873.

Ojiako, U., Papadopoulos, T., Stamati, T., Anagnostopoulos, D., and Marshall, A. 2015b. Collaborative governance in Greek infrastructure projects. Proceedings of the Institution of Civil Engineers: Management, Procurement and Law 168 (3): 135-145.

Oliveira, E., Alencar, L. and Costa, A. 2018. "Decision process of allocating projects to project managers." Production Planning \& Control DOI: 10.1080/09537287.2018.1432086.

Ouchi, W. 1977. The relationship between organizational structure and organizational control." Administrative Science Quarterly 20: 95-113.

Parkhe, A. 1991. "Interfirm diversity, organizational learning, and longevity in global strategic alliances.” Journal of International Business Studies 22: 579-602.

Patel, P., Messersmith, J., and Lepak, D. 2013. "Walking the tightrope: An assessment of the relationship between high-performance work systems and organizational ambidexterity." Academy of Management Journal 56(5): 1420-1442.

Petro, Y., Ojiako, U., Williams, T. and Marshall, A. 2018. Organizational ambidexterity: a critical review and development of a project focused definition, ASCE Journal of Management in Engineering DOI: 10.1061/(ASCE)ME.1943-5479.0000685.

Piao, M. and Zajac, E., 2016. "How exploitation impedes and impels exploration: Theory and evidence." Strategic Management Journal 37(7): 1431-1447.

Pinto, J. 2000. "Understanding the role of politics in successful project management1." International Journal of Project Management 18(2): 85-91.

Project Management Institute (PMI). 2013. A guide to the project management body of knowledge. Fifth edition. Newtown Square, PA.

Prado, P., and Sapsed, J. 2016. "The anthropophagic organization: How innovations transcend the temporary in a project-based organization." Organization Studies 37 (12): 1793-1818.

Raisch, S., Birkinshaw, J., Probst, G., and Tushman, M. 2009. "Organizational ambidexterity: Balancing exploitation and exploration for sustained performance.” Organization Science 20(4): 685-695.

Raisch, S. and Zimmermann, A. 2017. Pathways to Ambidexterity: A Process Perspective on the Exploration-Exploitation Paradox. In Smith, Wendy; Lewis, Marianne; Jarzabkowski, Paula \& 
Langley, Ann (ed.): The Oxford Handbook of Organizational Paradox. Oxford: Oxford University Press, 2017, S. 315-332.

Rogan, M. and Mors, M. 2014. "A network perspective on individual-level ambidexterity in organizations." Organization Science 25(6):1860-1877.

Rogers, T. 1976. "Interviews by telephone and in person: Quality of responses and field performance." Public Opinion Quarterly 40(1): 51-65.

Roldán Bravo, M., Lloréns Montes, F. and Ruiz Moreno, A. 2017. “Open innovation and quality management: the moderating role of interorganisational IT infrastructure and complementary learning styles." Production Planning \& Control 28(9): 744-757.

Rolstadås, A. 1994. "Editorial Project management." Production Planning \& Control 5 (1): 1

Rousseau, D. 1985. "Issues of level in organizational research: Multilevel and cross-level perspectives." Research in Organizational Behaviour 7: 1-37.

Sandberg, J. 2000. "Understanding human competence at work: An interpretative approach.” Academy of Management Journal 43(1): 9-25.

Scarbrough, H., Swan, J., Laurent, S., Bresnen, M., Edelman, L. and Newell, S. 2004. "Project-based learning and the role of learning boundaries." Organization Studies 25(9): 1579-1600.

Şimşit, Z., Günay, N. and Vayvay, Ö., 2014. "Theory of constraints: A literature review." ProcediaSocial and Behavioural Sciences 150: 930-936.

Sinha, S. 2016. "Managing an ambidextrous organization: balancing innovation and efficiency." Strategic Direction 32 (10): 35-37.

Sohani, S. and Singh, M., 2017. "Multilevel analysis of ambidexterity and tagging of specialised projects in project-based information technology firms." International Journal of Operations \& Production Management 37(9):1185-1206.

Stephens, N. 2007. "Collecting data from elites and ultra elites: telephone and face-to-face interviews with macroeconomists." Qualitative Research 7(2): 203-216.

Stettner, U. and Lavie, D. 2014. "Ambidexterity under scrutiny: Exploration and exploitation via internal organization, alliances, and acquisitions.” Strategic Management Journal 35(13): 1903-1929.

Taylor, A. and Helfat, C. 2009. 'Organizational linkages for surviving technological change: Complementary assets, middle management, and ambidexterity.' Organization Science 20(4): 718739.

Teece, D., Peteraf, M., and Leih, S. 2016. "Dynamic capabilities and organizational agility." California Management Review 58(4): 13-35.

Teller, J., Unger, B., Kock, A. and Gemünden, H. 2012. "Formalization of project portfolio management: The moderating role of project portfolio complexity." International Journal of Project Management 30(5): 596-607.

Tempelaar, M. and Rosenkranz, N. 2017. "Switching hats: the effect of role transition on individual ambidexterity." Journal of Management p.0149206317714312.

Tiwana, A., 2008. "Do bridging ties complement strong ties? An empirical examination of alliance ambidexterity." Strategic Management Journal 29(3):251-272.

Turner, N. and Lee-Kelley, L. 2013. "Unpacking the theory on ambidexterity: An illustrative case on the managerial architectures, mechanisms and dynamics.” Management Learning 44(2):179-196.

Turner, N., Swart, J. and Maylor, H. 2013a. "Mechanisms for managing ambidexterity: A review and research agenda." International Journal of Management Reviews 15(3):317-332.

Turner, N., Maylor, H. and Swart, J. 2013b. "Ambidexterity in managing business projects -an intellectual capital perspective.” International Journal of Managing Projects in Business 6(2):379389. 
Turner, N., Maylor, H., Lee-Kelley, L., Brady, T., Kutsch, E., and Carver, S. 2014. "Ambidexterity and knowledge strategy in major projects: A framework and illustrative study." Project Management Journal 45(5): 44-55.

Turner, N., Maylor, H., and Swart, J. 2015. "Ambidexterity in projects: An intellectual capital perspective." International Journal of Project Management 33: 177-188.

Turner, N., Swart, J., Maylor, H., and Antonacopoulou, E. 2016a. "Making it happen: How managerial actions enable project-based ambidexterity." Management Learning 47(2): 199-222.

Turner, N., Kutsch, E. and Leybourne, S.A., 2016b. Rethinking project reliability using the ambidexterity and mindfulness perspectives. International Journal of Managing Projects in Business 9(4): 845864.

Turner, N., Aitken, J. and Bozarth, C. 2018. "A framework for understanding managerial responses to supply chain complexity." International Journal of Operations \& Production Management 38(6): 1433-1466.

Tushman, M., and O’Reilly, C. 1996. “Ambidextrous organizations: Managing evolutionary and revolutionary change." California Management Review 38: 8-30.

Unger, B., Gemünden, H. and Aubry, M. 2012. "The three roles of a project portfolio management office: Their impact on portfolio management execution and success." International Journal of Project Management 30(5): 608-620.

van Marrewijk, A., Ybema, S., Smits, K., Clegg, S. and Pitsis, T. 2016. "Clash of the titans: Temporal organizing and collaborative dynamics in the Panama Canal megaproject." Organization Studies 37(12): 1745-1769.

Vedder, R. and Guynes, C. 2002. "CIOs' perspectives on competitive intelligence." Information Systems Management 19(4):49-55.

Verma, D. and Sinha, K. 2002. "Toward a theory of project interdependencies in high tech R\&D environments.” Journal of Operations Management 20(5): 451-468.

Verma, D., Mishra, A. and Sinha, K., 2011. "The development and application of a process model for R\&D project management in a high tech firm: A field study." Journal of Operations Management 29(5): 462-476.

Wang, C.L. and Rafiq, M. 2014. "Ambidextrous Organizational Culture, Contextual Ambidexterity and New Product Innovation: A Comparative Study of UK and Chinese High-tech Firms." British Journal of Management 25(1): 58-76.

Wassmer, U., Li, S., and Madhok, A. 2017. "Resource ambidexterity through alliance portfolios and firm performance." Strategic Management Journal 38 (2): 384-394.

Weber, M. 1949. The Methodology of the Social Sciences, Free Press.

Wei, Z., Zhao, J., and Zhang, C. 2014. "Organizational ambidexterity, market orientation, and firm performance." Journal of Engineering and Technology Management 33: 134-153.

Zimmermann, A., Raisch, S., and Birkinshaw, J. 2015. "How is ambidexterity initiated? The emergent charter definition process." Organization Science 26(4): 1119-1139.

Zimmermann, A., Raisch, S., and Cardinal, L. 2018. "Managing persistent tensions on the frontline: A configurational perspective on ambidexterity." Journal of Management Studies 55 (5), 739-769. 